\title{
高強度異形鉄筋を用いた鉄筋コンクリートばり \\ の疲労に関する基礎研究 \\ FUNDAMENTAL STUDY ON FATIGUE BEHAVIOUR OF REINFORCED
CONCRETE BEAMS USING HIGH STRENGTH DEFORMED BARS
}

国 分正扸* ・岡 村 甫** By Masatane Kokubu and Hajime Okamura

\section{1. 序論}

高強度異形鉄筋を適当に用いれば，その降伏点に応じ て部材の破壊強度が増大し鉄筋量も節約できるので, こ こ数年来わが国における高強度異形鉄筋の使用は増加の 一途をたどっている。しかし，高強度鉄筋を用いてその 許容引張応力度を大きくとると, 設計荷重が作用する場 合に生ずるコンクリートのひびわれの幅が比較的大きく なり，風雨にさらされる場合鉄筋がさびて部材の耐久性 を損なうおそれもある。そのため高強度鉄筋は，一般に 異形鉄筋とする必要があるが, 鉄筋にフシを設け異形鉄 筋とすると, フシの周辺に働く応力集中の影響で，その 疲労強度がある程度低下することが考えられる。したが って，鉄道橋のように鉄筋に大きなくり返し応力 が作用する部材に高強度異形鉄筋を用いる場合に は，その降伏点が高いからといって許容応力度を 大きくとると，鉄筋の疲労破断によって部材が破 壊するおそれもある。

近年わが国では異形鉄筋の疲労強度に関する研 究は多く，すでに結果が公表されているものもあ

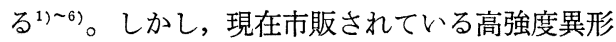
鉄筋の形状その他は各種各様であって，その疲労 強度も相違するのは当然である。また，くり返し 載荷をうける鉄筋コンクリートばりにおけるひび われその他の曲げ性状は，用いる鉄筋の影響を受 けるだけではなく，はりの断面形状抢よび鉄筋比その他 の影響をも相当に受けることが考えられる。

東京大学土木教室では, 昭和 38 年以来異形鉄筋の疲 労に関連する基礎研究を続けている。本文は，それらの 研究結果を取りまとめたもので, 各種高強度異形鉄筋を 用いた鉄筋コンクリートばりの疲労性状について論じた ものである。

研究の実施に当り, 終始熱心核実験に従事して下さっ た東京大学土木教室コンクリート研究室の方々に厚くお 礼申し上げる。また文部省より科学研究費交付金を交付 されたことを付記して厚くお礼申し上げる。

$*$ 正会員 工博 東京大学教授 工学部土木工学科

** 正会員 工修 東京大学工学部土木工学科

\section{2. 使用材料および試験方法}

(1) コンクリート

a) コンクリート材料 セメントは日本セメント会 社製の普通ポルトランド セメントを用いたが，一部の 試験には早強ポルトランド セメントをも用いた。それ らの試験成績は 表一1 に示すようである。砂は富士川産 のもので,その比重は 2.63 であった。砂利は荒川産のも ので, その比重は 2.64 であった。それらのふるい分け 試験の結果は図一1 に示すようである。ポゾリス No. 5 はセメント重量の $0.5 \%$ を用い, あらかじめ $10 \%$ 溶液 としておいて用いた。

b）配合 コンクリートの配合は大部分のものは表 表一1 セメントの試験成績

\begin{tabular}{|c|c|c|c|c|c|c|c|c|c|c|}
\hline \multirow[b]{2}{*}{ 種 } & \multirow[b]{2}{*}{ 別 } & \multirow[b]{2}{*}{ 比重 } & \multicolumn{2}{|c|}{ 粉 末 度 } & \multicolumn{3}{|c|}{ 凝 } & \multicolumn{2}{|c|}{ 結 } & \multirow{2}{*}{$\begin{array}{l}\text { 安定性 } \\
\left(\begin{array}{c}\text { 著沸 } \\
(\text { 去 }\end{array}\right)\end{array}$} \\
\hline & & & 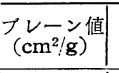 & $\begin{array}{l}88 \mu \\
\text { 残分 }\end{array}$ & $\begin{array}{l}\text { 聜温 } \\
\left({ }^{\circ} \mathrm{C}\right)\end{array}$ & $\begin{array}{l}\text { 湿度 } \\
(\%)\end{array}$ & $\begin{array}{l}\text { 水量 } \\
(\%)\end{array}$ & $\begin{array}{l}\text { 姾 発) } \\
(\text { 時-分) }\end{array}$ & $\begin{array}{l}\text { 終 結 } \\
\text { (时-分) }\end{array}$ & \\
\hline \multicolumn{2}{|c|}{$\begin{array}{l}\text { 普通ポルトラ } \\
\text { ジセント }\end{array}$} & 3.16 & 3470 & 2.1 & 20.3 & 93 & 27.9 & $2-20$ & 3-35 & 良 \\
\hline \multicolumn{2}{|c|}{$\begin{array}{l}\text { 早強ポルトラ } \\
\text { シセセント }\end{array}$} & 3.14 & 4420 & 0.2 & 20.0 & 95 & 29.9 & $2-40$ & $4-07$ & 良 \\
\hline
\end{tabular}

\begin{tabular}{|c|c|c|c|c|c|c|c|c|c|c|}
\hline \multirow{2}{*}{ 種 } & \multirow{2}{*}{ 別 } & \multirow{2}{*}{$\begin{array}{c}\text { フロー値 } \\
(\mathrm{mm})\end{array}$} & \multicolumn{4}{|c|}{ 曲げ強度 $\left(\mathrm{kg} / \mathrm{cm}^{2}\right)$} & \multicolumn{4}{|c|}{ 压縮 強度 $\left(\mathrm{kg} / \mathrm{cm}^{2}\right)$} \\
\hline & & & 1 日 & 3 日 & 7 日 & 28 日 & 1 日 & 3 日 & 7 日 & 28日 \\
\hline & & 242 & - & 34.3 & 50.7 & 72.4 & - & 135 & 239 & 429 \\
\hline & & 254 & 27.2 & 50.6 & 65.1 & 82.0 & 104 & 238 & 367 & 505 \\
\hline
\end{tabular}

図一1骨材のふるい分け試験

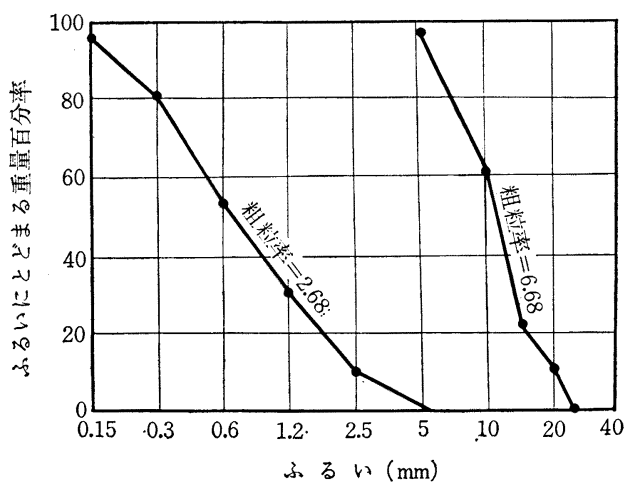


表一2 コンクリートの配合および試験結果

\begin{tabular}{|c|c|c|c|c|c|c|c|c|c|c|c|c|c|}
\hline \multirow{2}{*}{ 番 号 } & \multirow{2}{*}{ 也 } & \multirow[t]{2}{*}{$x$} & \multirow[t]{2}{*}{ 卜 } & \multirow{2}{*}{ 混 } & \multirow{2}{*}{ 和 } & \multirow{2}{*}{$\begin{array}{c}\text { 粗骨材の } \\
\text { 最大寸法 } \\
(\mathrm{mm})\end{array}$} & \multirow{2}{*}{$\begin{array}{l}\begin{array}{l}\text { 水セxン } \\
\vdash\end{array} \\
(\%)\end{array}$} & \multirow{2}{*}{$\begin{array}{l}\text { 単位七量 } \\
\text { 量 } \\
\left(\mathrm{kg} / \mathrm{m}^{3}\right)\end{array}$} & \multirow{2}{*}{$\begin{array}{c}\text { 細骨材率 } \\
(\%)\end{array}$} & \multirow{2}{*}{$\begin{array}{c}\text { スランプ } \\
(\mathrm{cm})\end{array}$} & \multirow{2}{*}{$\begin{array}{c}\text { 空気 量 } \\
\text { (\%) }\end{array}$} & \multicolumn{2}{|c|}{ 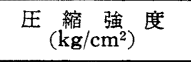 } \\
\hline & & & & & & & & & & & & 材命14日 & 材令28日 \\
\hline 1 & 普通ポル & トラント & ト セメント & ポゾリス & No. 5 & 25 & 55 & 255 & 38 & 6 & 3.5 & - & 350 \\
\hline 2 & 普通ポル & トラン | & ド セメント & & 2 & 15 & 55 & 327 & 49 & 10 & 1.5 & - & 330 \\
\hline 3 & 早強ポル & トラント & ド セメント & ポゾリス & No. 5 & 25 & 55 & 260 & 39 & 6 & 2.5 & 380 & - \\
\hline
\end{tabular}

-2 に示す配合 1 であり，一部の試験には配合 2 および 配合 3 をも用いた。試験は材令 28 日以後に開始した が，早強ポルトランド セメントを用いたものは材令 14 日以後に開始した。試験時におけるコンクリートの圧縮 強度は, 試験期間が長期にわたったため多少ばらついた が平均約 $350 \mathrm{~kg} / \mathrm{cm}^{2}$ であった。

c）練り混ぜ・締め固めおよび養生コンクリート の練り混ぜに当っては, バッチの大きさを $80 \sim 120 l$ と し，バレル型可傾式ミキサを用い 3 分間練り混ぜた。コ ンクリートは棒状振動機を用いて入念に締め固めた。供 試体は材令 2 日に脱わくし, 実験室内で, 試験開始の 2 〜 3 日前まで, コンクリート上面を湿布でおおって養生 した。

\section{（2）鉄筋}

用いた鉄筋は，いずれも熱間圧延したもので，JIS G $3112^{7}$ “ “鉄筋コンクリート用棒鋼” 汇適合する異形鉄筋 17 種およびこれに適合しない異形鉄筋 1 種であって, 比較のために普通丸鋼 SR 30 をも用いた。18 種の異形
鉄筋には SD 35 が 3 種, SD 40 が 11 種, SD 50 が 2 種ふくまれており, 大部分のものはいわゆる高強度異形 鉄筋である。それらの形状は写真一1に, 機械的性質お よび化学成分は 表一3に示すようである。

$\mathrm{A} ： \mathrm{SR} 30$ の普通丸鋼である。

$\mathrm{B}: \mathrm{SD} 30$ の直角フシの異形鉄筋であり, 従来から広 く用いられてきたものである。

$\mathrm{C}_{1}$ : フシと鉄筋軸とのなす角度が $60^{\circ}$ の異形鉄筋で, 旧型に属するものである。

$\mathrm{C}_{2}$ : フシの配置は $\mathrm{C}_{1}$ と同じであるが,フシが鉄筋母材 にとりつく所の勾配の急変を緩和するため, フシ の高さの $1 / 3$ 程度から下の部分を, フシの高さの 9 倍程度の半径をもつ円孤とした市販品である。

$\mathrm{C}_{3}$ : フシの配置は $\mathrm{C}_{1}$ および $\mathrm{C}_{2}$ と同じであるが，フシ のとりつけをフシの高さの 5 倍程度の半径をむつ 円孤とした異形鉄筋で,旧型に属するものである。 $\mathrm{D}$ ：フシと鉄筋軸とのなす角度が $30^{\circ}$ の波フシ型の異 形鉄筋で, フシの間隔およびフシのすきまも JIS

表一3 鉄 筋 の 試 倹 結 果

\begin{tabular}{|c|c|c|c|c|c|c|c|c|c|c|c|c|c|c|c|c|c|c|c|}
\hline \multirow{3}{*}{$\begin{array}{c}\text { 直径 } \\
(\mathrm{mm})\end{array}$} & \multirow{3}{*}{ 種 } & \multirow{3}{*}{ 類* } & \multirow{3}{*}{ 規 标 } & \multicolumn{3}{|c|}{ 機 械 的 性 質*** } & \multicolumn{3}{|c|}{ 形 } & \multicolumn{4}{|c|}{ 状 } & \multicolumn{4}{|c|}{ 化 } & \multicolumn{2}{|l|}{$(\%)$} \\
\hline & & & & \multirow{2}{*}{$\begin{array}{l}\text { 降 伏 点 } \\
\left(\mathrm{kg} / \mathrm{mm}^{2}\right)\end{array}$} & \multirow{2}{*}{$\begin{array}{c}\text { 引張強さ } \\
\left(\mathrm{kg} / \mathrm{mm}^{2}\right)\end{array}$} & \multirow{2}{*}{$\begin{array}{l}\text { 伸び } \\
(\%)\end{array}$} & \multirow{2}{*}{$\begin{array}{l}\text { 平均 } \\
\text { 断面皘 } \\
\left(\mathrm{cm}^{2}\right)\end{array}$} & \multirow{2}{*}{\begin{tabular}{|l|} 
フンンと \\
軸との \\
なすす角
\end{tabular}} & \multirow{2}{*}{ 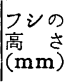 } & \multicolumn{2}{|c|}{$\begin{array}{c}\text { フシの 幅 } \\
(\mathrm{mm})\end{array}$} & \multirow{2}{*}{$\left|\begin{array}{l}\text { フ⿵ } \\
\text { 間 } \\
(\mathrm{mm})\end{array}\right|$} & \multirow{2}{*}{$\begin{array}{l}\text { yフ } \\
\text { の幅 } \\
(\mathrm{mm})\end{array}$} & \multirow[t]{2}{*}{ C } & \multirow[t]{2}{*}{$\mathrm{Mn}$} & \multirow[t]{2}{*}{$\mathrm{Si}$} & \multirow[t]{2}{*}{$\mathrm{P}$} & \multirow[t]{2}{*}{$\mathrm{S}$} & \multirow{2}{*}{$\mathrm{C}+\frac{\mathrm{Mn}}{6}$} \\
\hline & & & & & & & & & & 最小 & 最大 & & & & & & & & \\
\hline \multirow{13}{*}{19} & A & 30 & SR 30 & 38 & 58 & 29 & 2.86 & - & - & - & - & - & - & 0.20 & 1.18 & 0.30 & $|0.020|$ & 0.017 & 0.40 \\
\hline & B & 30 & SD 30 & 32 & 53 & 26 & 2.79 & $90^{\circ}$ & 1.3 & 1.8 & 3.0 & 12.5 & 3.5 & 0.33 & 0.52 & 0.11 & 0.013 & 0.022 & 0.42 \\
\hline & $\mathrm{C}_{1}$ & 35 & SD 35 & 39 & 60 & 27 & 2.79 & $60^{\circ}$ & 1.7 & 3.0 & 5.5 & 12.4 & 3.7 & 0.22 & 1.29 & 0.33 & 0.024 & 0.022 & 0.44 \\
\hline & $\mathrm{C}_{1}$ & & SD 40 & 44 & 59 & 23 & 2.92 & $60^{\circ}$ & 1.9 & 2.5 & 5.5 & 12.4 & 4.5 & 0.26 & 0.97 & 0.06 & 0.024 & 0.017 & 0.42 \\
\hline & $\mathrm{C}_{1}$ & & SD 50 & 54 & 72 & 23 & 2.80 & $60^{\circ}$ & 1.4 & 2.5 & 5.0 & 12.5 & 4.0 & 0.27 & 1.32 & 0.27 & 0.023 & 0.025 & 0.49 \\
\hline & $\mathrm{C}_{3}$ & & SD 40 & 46 & 60 & 26 & 2.78 & $60^{\circ}$ & 1.5 & 2.5 & 7.0 & 12.4 & 4.0 & 0.17 & 1.19 & 0.34 & 0.041 & 0.027 & 0.37 \\
\hline & D & 40 & - & 49 & 67 & 23 & 2.79 & $30^{\circ}$ & 1.4 & 2.2 & 8.0 & 24.0 & 4.0 & 0.21 & 1.19 & 0.34 & 0.041 & 0.027 & 0.41 \\
\hline & $\mathrm{E}$ & 40 & SD 40 & 42 & 65 & 22 & 2.83 & $90^{\circ}$ & 1.3 & 2.0 & 4.0 & 12.3 & 4.0 & 0.28 & 1.05 & 0.43 & 0.019 & 0.014 & 0.46 \\
\hline & $\mathrm{E}$ & 60 & $\mathrm{SD} 60^{* *}$ & 61 & 84 & 16 & 2.85 & $90^{\circ}$ & 1.4 & 2.0 & 3.5 & 12.4 & 4.0 & 0.32 & 1.53 & 0.52 & 0.017 & 0.019 & 0.58 \\
\hline & $F$ & 35 & SD 35 & 40 & 63 & 26 & 2.84 & $45^{\circ}$ & 1.5 & 2.0 & 3.5 & 10.7 & 2.4 & - & - & - & -1 & - & - \\
\hline & $\mathbf{F}$ & 40 & $\mathrm{SD} 40$ & 43 & 67 & 24 & 2.86 & $45^{\circ}$ & 1.5 & 2.0 & 3.5 & 10.9 & 2.5 & - & - & - & - & - & - \\
\hline & G & 40 & SD 40 & 44 & 66 & 23 & 2.77 & $90^{\circ}$ & 1.2 & 2.8 & 5.0 & 12.0 & 5.2 & 0.25 & 1.60 & 0.44 & $0.040 \mid$ & 0.018 & 0.51 \\
\hline & $\mathrm{H}$ & 40 & SD 40 & 42 & 61 & 21 & 2.82 & $90^{\circ}$ & 1.6 & 3.0 & 4.5 & 13.6 & 4.1 & 0.24 & 1.46 & 0.30 & 0.015 & 0.019 & 0.51 \\
\hline & B & 30 & SD 30 & 30 & 53 & 2 & 4.92 & $90^{\circ}$ & 1.6 & 2.0 & 3.5 & 16.0 & 4.7 & 0.34 & 0.52 & 0.10 & $|0.014|$ & 0.020 & 0.43 \\
\hline & $\mathrm{C}_{2}$ & 40 & SD 40 & 48 & 64 & 23 & 5.01 & $60^{\circ}$ & 2.2 & 3.5 & 8.0 & 16.5 & 5.0 & 0.23 & 1.21 & 0.36 & 0.039 & 0.025 & 0.43 \\
\hline & $\mathrm{C}_{3}$ & 35 & SD 35 & 40 & 55 & 29 & 4.93 & $60^{\circ}$ & 1.8 & 3.2 & 8.0 & 17.0 & 4.5 & 0.17 & 1.15 & 0.34 & 0.039 & 0.018 & 0.34 \\
\hline & $\mathrm{E}$ & 40 & SD 40 & 42 & 64 & 22 & 5.07 & $90^{\circ}$ & 2.0 & 3.2 & 7.0 & 16.3 & 5.0 & 0.24 & 1.23 & 0.42 & 0.025 & 0.029 & 0.44 \\
\hline & $\mathrm{F}$ & 40 & SD 40 & 42 & 66 & 24 & 5.03 & $45^{\circ}$ & 1.5 & 3.0 & 4.1 & 15.4 & 4.0 & 0.23 & 1.63 & 0.50 & 0.022 & 0.029 & 0.50 \\
\hline 2 & G & 40 & $\mathrm{SD} 40$ & 42 & 64 & 23 & 5.06 & $90^{\circ}$ & 1.5 & 3.0 & 5.1 & $\mid 16.0$ & 7.0 & 0.25 & 1.60 & 0.44 & 0.040 & 0.018 & 0.52 \\
\hline & $\mathrm{I}_{1}$ & 40 & SD 40 & 42 & 60 & 21 & 4.90 & $75^{\circ}$ & 2.0 & 4.0 & 5.0 & 17.0 & 4.9 & 0.21 & 1.50 & 0.43 & 0.014 & 0.014 & 0.46 \\
\hline & $\mathrm{I}_{2}$ & 40 & SD 40 & 47 & 62 & 28 & 5.11 & $75^{\circ}$ & 1.6 & 2.5 & 8.0 & $\mid 17.8$ & 7.5 & 0.20 & 1.57 & 0.34 & 0.024 & 0.015 & 0.46 \\
\hline & $\mathrm{I}_{3}$ & 40 & SD 40 & 51 & 68 & 23 & 5.03 & $75^{\circ}$ & 1.9 & 1.5 & 8.0 & 18.5 & 8.5 & 0.20 & 1.57 & 0.34 & 0.024 & 0.015 & 0.46 \\
\hline & $\mathbf{J}$ & 40 & SD 40 & 42 & 63 & 23 & 5.00 & $60^{\circ}$ & 1.3 & 2.5 & 10.0 & 14.0 & 9.0 & 0.23 & 1.39 & 0.32 & $\mid 0.014$ & 0.021 & 0.46 \\
\hline 備 & & 考 & $* *$ 烸 & . & 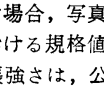 & & & 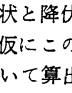 & 25 & & & & & & & & & & \\
\hline
\end{tabular}


写真一1 鉄筋 の 形 状

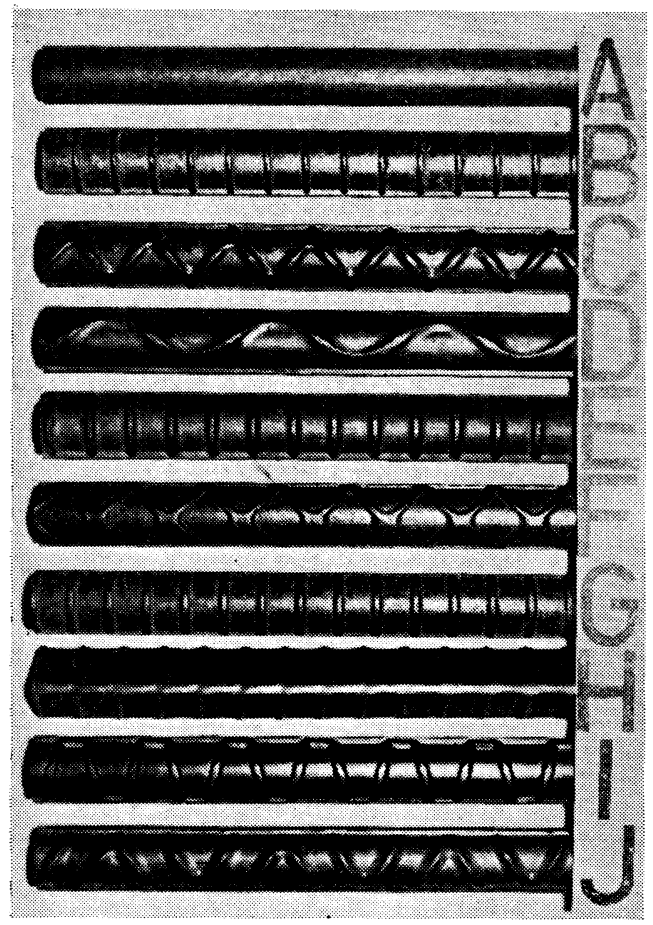

規格よりもはるかに大きく，フシのとりつけも円 坬で行なった。特に耐疲労性を考慮した試作品で ある。

$\mathrm{E}:$ 直角フシの異形鉄筋で, フシの高さの $1 / 3$ 程度か ら下の部分を，フシの高さ程度の半径をもつ円孤 とした市販品である。

F：フシと鉄筋軸とのなす角度が $45^{\circ}$ の斜めフシの異 形鉄筋で，市販品である。

$\mathrm{G}$ : 直角フシの異形鉄筋で最近まで市販されていた が，その後改良されたと聞いており，旧型に属し ている。

$\mathrm{H}$ : 三角形断面の異形鉄筋で, フシと鉄筋軸とのなす 角度が $90^{\circ}$ の市販品である。

$\mathrm{I}_{1}$ : フシと鉄筋軸とのなす角度が $75^{\circ}$ の斜めフシの異 形鉄筋で，旧型に属するものである。

$\mathrm{I}_{2}$ : フシの配置は $\mathrm{I}_{1}$ と同じであるが，フシのとりつ けをフシの高さの 2 倍程度の半径をもつ円孤で行 なった市販品である。

$I_{3}$ : フシの配置は $I_{1}$ および $I_{2}$ と同じであるが，フ シのとりつけをフシの高さの 5 倍程度の半径をも つ円孤で行なった試作品である。

$\mathrm{J}$ ：フシと鉄筋軸とのなす角度が $60^{\circ}$ の斜めフシの異 形鉄筇で,フシの高さを規格の限度まで小さくし， フシの上部を滑めらかにするとともにそのとりつ けも大きい半径の円孤で行なった試作品である。 鉄筋の表示に当っては, 上記の形状と降伏点の規格值 とで示すことにした。
写真一2 疲労試験装居

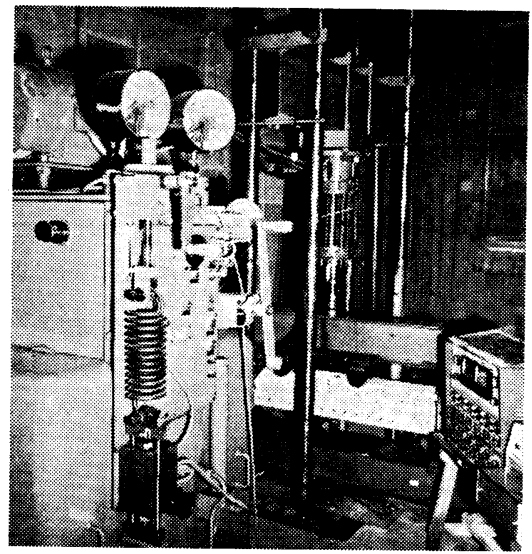

（3）疲労試験方法

試験の様子は 写真一2 に示すようであって，用いた疲 労試験機は前川試験機製作所製で, 容量 $10 \mathrm{t}$, 載荷速度 毎分 300 回のものである。支点および載荷点のローラー にはボール ベアリングを用いてあるが，載荷にともな ってローラーは回転し，自由支承として働いていること が確かめられた。動的に載荷する場合の荷重の検定は, ジャッキの下にロード セルをそう入して行なった。ス パンは $120 \mathrm{~cm}$ あるいは $129 \mathrm{~cm}$ とし，載荷点の間隔を $40 \mathrm{~cm}$ とした 2 点載荷とした。

疲労試験開始前，および載荷回数がそれぞれ 1000,1 $\times 10^{4}, 10 \times 10^{4}, 50 \times 10^{4}, 100 \times 10^{4}, 200 \times 10^{4}$ に達した時 に試験機の運転を停止し, 上限荷重 まで静的に載荷し て、コンクリートのひずみ, たわみ, ひびわれの幅等を 測定した。一部の試験では疲労試験中の鉄筋およびュン クリートのひずみを, 動的ひずみ測定器および電磁オッ シログラフを用いて測定した。鉄筋のひずみを測定す るためゲージを貼ると，そのすぐ近くで鉄筋が破断する ことの多いことが示されたので，荷重の検定その他特に 必要のある場合のほかは, 鉄筋のひずみは実測しなかっ た。鉄筋にゲージを貼った場合でも, 疲労試験の途中で 測定不能となることが多かった。コンクリートのひずみ はワイヤ ストレィン ゲージあるいはコンタクトゲー ジを用いて測定した。スパン中央および支点から 10 $\mathrm{cm}$ の位置のたわみをダイアル ゲージで測定し，支点 沈下および支承部コンクリートの変形等の影響を除くた め, 前者と後者との差をたわみの試験值とした。

ひびわれ幅はコンタクトゲージを用いて測定した。 すなわち，供試体側面で，鉄筋の重心位置に，あらかじ め $6 \mathrm{~cm}$ 間隔にコンタクトゲージ用ボールを打込んだ鋼 小板を貼りつけておいて，その間の長さ変化を測定し (図一2 参照)，ひびわれを生じなかった区間の平均縮み とひびわれを生じた区間の伸びとの代数和をひびわれ幅 としたのである ${ }^{8)}$ 。スパン中央部の長さ $72 \mathrm{~cm}$ (載荷点 の間隔＋有効高さの 2 倍) の区間におけるひびわれの最 
図一2 最大ひびわれ幅および平均ひびわれ幅の定め方
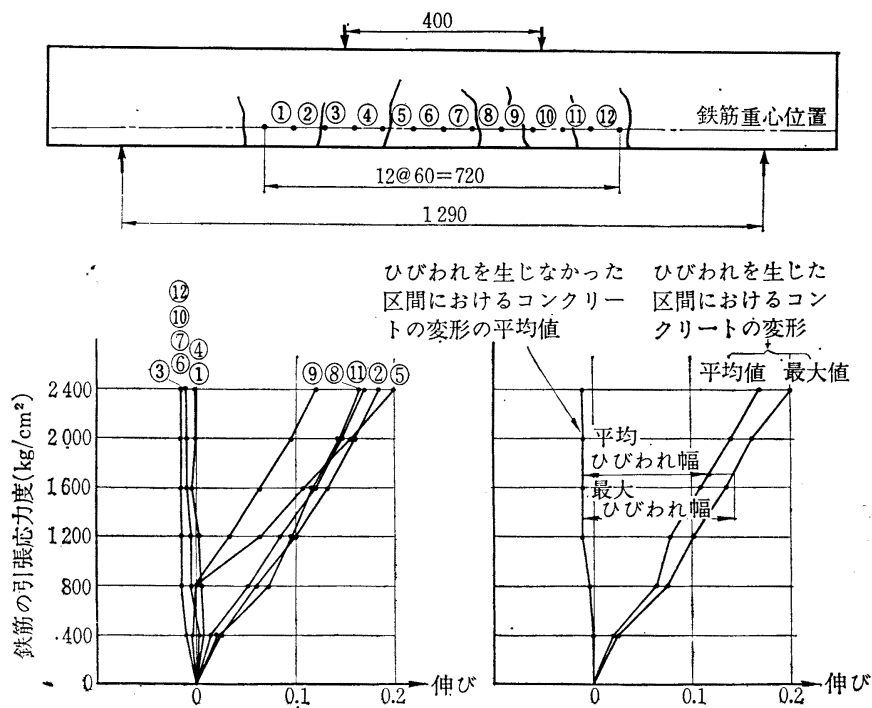

各標点間における長さ变化 $(\mathrm{mm})$

図一3 供試体の形状および寸法
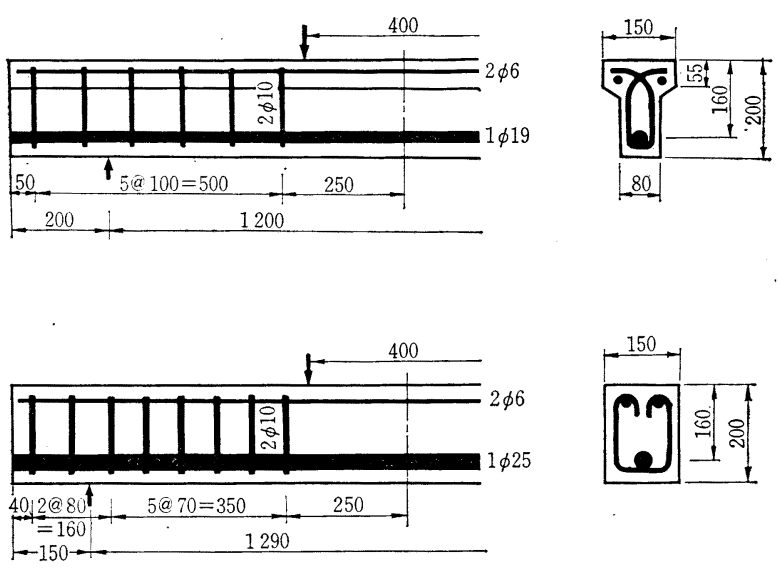

大幅を最大ひびわれ幅, ひびわれの平均幅を平均ひびわ れ幅と称することとした。

\section{3. 異形鉄筋の相違がはりの疲労性状におよぼ す影響}

合計 81 本の鉄筋コンクリートばりについて, 異形鉄 筋の相違が，鉄筋コンクリートばりの疲労性状におよぼ す影響を検討した。用いた異形鉄筋は形状および材質の 異なる 18 種の鉄筋であって, 昭和 40 年 2 月現在の代表 的市販品 8 種をふくんでいる。用いた供試体は 図-3に 示すような T型ばり (值径 $19 \mathrm{~mm}$ の場合) および矩 形ばり (直径 $25 \mathrm{~mm}$ の場合) であって，スパンをそれぞ れ $120 \mathrm{~cm}$ および $129 \mathrm{~cm}$ として曲げ疲労試験を行なっ た。鉄筋を配置する場合, ごく小数のはりを除き，引張 鉄筋端にもフックは設けなかった。

疲労試験は,一般に破壊に至るまで続行し, 200 万回の
載荷によっても破壊しない場合には，200 万回でこれを中止した。なお一部に，200 万回以上継続したものもある。疲労試験に おける下限荷重は, コンクリートの引張応 力を無視し $n$ を 15 として弾性理論によっ て計算した鉄筋の応力度が $400 \mathrm{~kg} / \mathrm{cm}^{2}$ と なるような荷重としたが，その場合の鉄筋 応力度の実測值は 1 回目の載荷を除き 700 $\sim 900 \mathrm{~kg} / \mathrm{cm}^{2}$ であった。上限荷重は, 各 鉄筋ごとに 200 万回疲労強度が得られるよ らに定めた。これを定める場合には，あら かじめ適当な上限荷重たとえば鉄筋応力度 が $2800 \mathrm{~kg} / \mathrm{cm}^{2}$ となるような荷重で疲労 試験を行ない，その疲労破断までの載荷回 数から本試験における上限荷重を定めた (上限荷重時の鉄筋応力度の実測值は, ひ びわれ近傍では計算值と同様であった)。 試験の結果から，200 万回のくり返し載荷 で疲労破断するような上限荷重に相当する鉄筋応 力度を求め ( $(1)$ 参照), 200 万回疲労強度と呼 び,これにもとづいて鉄筋の疲労強度を論じたの である。最初の間は，同一の鉄筋について一般に 4 本以上の供試体を用いて疲労試験を行なった が, 試験の後半には, 少数の供試体による試験結 果から 200 万回疲労強度が推定できた。

\section{（1）鉄筋の疲労強度}

疲労強度の試験結果は 表一4 および表一5 亿示 すようであって，この結果から 200 万回疲労強度 を求めると表一 6 に示すようになる。疲労試験の 結果には，比較的ばらつきが大きく供試体の数も 少ない場合もあったが，上限応力度と破壊するま での載荷回数との関係を片対数目盛で表わせば, 一般的に比例的な関係となるので(図一 4 参照)，この場 合にもこの関係が成り立つものとして表一6の值を推定 したのであって, 表一6 に示された值は妥当なものと信 じている。

はりの疲労強度は用いる鉄筋によっていちじるしく相 違し，各種異形鉄筋をその疲労強度によって区分する と， 3 グループに分けることができる。

第1グルーブは, 疲労強度が、ちじるしく高く, 200 万回疲労強度が $2800 \mathrm{~kg} / \mathrm{cm}^{2}$ 以上のものである。こ のグループに属する鉄筋は $\mathrm{C}_{2} 40, \mathrm{C}_{3} 40, \mathrm{E} 40, \mathrm{E} 60$, $\mathrm{I}_{2} 40, \mathrm{I}_{3} 40$ の 6 種である。 $\mathrm{E} 40$ および $\mathrm{E} 60$ は直角フ シであるが，その他のものはすべて斜めフシである。こ れらはいずれも, フシが鉄筋母材にとりつく所の勾配急 変が緩和されているものである。すなわち，フシのとり つけ部がフシの高さの 1 9 倍の半径をもつ円孤となっ ている (2. 参照)。 
表-4 疲 労 試 験 結 果 (鉄筋直径 $19 \mathrm{~mm}$ の場合)

\begin{tabular}{|c|c|c|c|c|c|c|c|c|c|c|}
\hline \multirow{3}{*}{ 鉄筋の種類 } & \multirow{3}{*}{ 番 号 } & \multirow{3}{*}{$\begin{array}{c}\text { 上限荷重作用 } \\
\text { 時にお る } \\
\text { 鉄筋応力度 } \\
\left(\mathrm{kg} / \mathrm{cm}^{2}\right)\end{array}$} & \multirow{3}{*}{$\begin{array}{l}\text { 載荷回数 } \\
\left(\times 10^{4}\right)\end{array}$} & \multirow{3}{*}{ 破断箇所* } & \multirow{2}{*}{\multicolumn{4}{|c|}{\begin{tabular}{c|c} 
最大ひびわ れ 幅 $(\mathrm{mm})$ \\
荷重を除去した時 & 上限荷重が作用した時
\end{tabular}}} & \multirow{3}{*}{$\mathrm{W}_{2} / \mathrm{W}_{1}$} & \multirow{3}{*}{$\begin{array}{l}\text { 鉄筋端における } \\
\text { フック有無 }\end{array}$} \\
\hline & & & & & & & & & & \\
\hline & & & & & 1 回 目 & 10 万回後 & 1 回 ${ }_{\mathrm{W}_{1}}$ & $\begin{array}{c}10 \text { 万回後 } \\
\mathrm{W}_{2}\end{array}$ & & \\
\hline \multirow{7}{*}{ A 30} & 1 & 2400 & 520 & 破断せず & 0.14 & 0.24 & 0.33 & 0.54 & 1.65 & 有 \\
\hline & 2 & 2400 & 213 & 破断せず & 0.08 & 0.21 & 0.19 & 0.47 & 2.45 & 有 \\
\hline & 3 & 2800 & 50 & A & 0.14 & 0.48 & 0.32 & 1.0 以上 & 3.0 以上 & 有 \\
\hline & 4 & 2800 & 47 & B & 0.09 & 0.37 & 0.26 & 0.86 & 3.30 & 有 \\
\hline & 5 & 3200 & 16 & A. & 0.17 & 0.40 & 0.50 & 0.80 & 1.60 & 有 \\
\hline & 6 & 3200 & 5 & A. & 0.11 & - & 0.32 & - & - & 有 \\
\hline & 7 & 3600 & 2 & A. & 0.22 & - & 0.40 & - & - & 有 \\
\hline \multirow{3}{*}{ B 30} & 1 & 2400 & 150 & A & 0.04 & 0.06 & 0.18 & 0.19 & 1.05 & \\
\hline & 2 & 2800 & 31 & A & 0.05 & - & 0.18 & - & - & \\
\hline & 3 & 2800 & 39 & A & 0.05 & 0.53 & 0.19 & 0.64 & 3.45 & \\
\hline \multirow{4}{*}{$C_{1} 40$} & 1 & 2800 & 59 & B & 0.04 & 0.05 & 0.19 & 0.20 & 1.05 & \\
\hline & 2 & 2800 & 153 & $\mathrm{C}$ & 0.04 & 0.05 & 0.15 & 0.16 & 1.05 & \\
\hline & 3 & 3200 & 38 & A & 0.05 & - & 0.21 & - & - & \\
\hline & 4 & 3200 & 50 & $\mathrm{~B}$ & 0.04 & 0.07 & 0.18 & 0.20 & 1.10 & \\
\hline \multirow{3}{*}{$C_{1} 35$} & 5 & 2800 & 128 & $\mathrm{C}$ & 0.04 & 0.06 & 0.18 & 0.19 & 1.10 & \\
\hline & 6 & 2800 & 101 & A & 0.04 & 0.05 & 0.15 & 0.20 & 1.30 & \\
\hline & 7 & 3200 & 46 & A & 0.06 & 0.07 & 0.24 & 0.25 & 1.05 & \\
\hline & 8 & 2800 & 47 & A. & 0.05 & 0.06 & 0.18 & 0.20 & 1.10 & \\
\hline & 9 & 2800 & 51 & A & 0.04 & 0.05 & 0.17 & 0.18 & 1.05 & \\
\hline$C_{1} 50$ & 10 & 2800 & 64 & B & 0.05 & 0.07 & 0.20 & 0.24 & 1.20 & \\
\hline & 11 & 3200 & 62 & A & 0.06 & 0.07 & 0.18 & 0.21 & 1.15 & \\
\hline & 12 & 3200 & 20 & A & 0.04 & - & 0.17 & - & - & \\
\hline & 1 & 2800 & 848 & A & 0.04 & 0.07 & 0.18 & 0.20 & 1.05 & \\
\hline & 2 & 2800 & 72 & B & 0.06 & 0.09 & 0.18 & 0.25 & 1.40 & \\
\hline & 3 & 2800 & 200 & 破断せず & 0.05 & 0.08 & 0.17 & 0.19 & 1.15 & \\
\hline $\mathrm{C}_{3} 40$ & 4 & 3200 & 190 & A & 0.06 & 0.09 & 0.21 & 0.24 & 1.15 & \\
\hline & 5 & 3200 & 106 & B & 0.05 & 0.08 & 0.21 & 0.24 & 1.15 & \\
\hline & 6 & 3200 & 90 & B & 0.07 & - & 0.22 & - & - & \\
\hline & 7 & 3600 & 77 & A & 0.05 & 0.10 & 0.22 & 0.26 & 1.20 & \\
\hline & 1 & 2800 & 186 & 破断せず & 0.07 & 0.12 & 0.18 & 0.29 & 1.65 & 有 \\
\hline D 40 & 2 & 3200 & 134 & A. & 0.09 & 0.13 & 0.25 & 0.38 & 1.50 & \\
\hline & 3 & 3600 & 41 & B & 0.10 & 0.17 & 0.32 & 0.52 & 1.65 & 有 \\
\hline & 1 & 2800 & 88 & C & 0.06 & 0.07 & 0.18 & 0.22 & 1.20 & \\
\hline & 2 & 2800 & 236 & 破断せず & 0.05 & 0.06 & 0.16 & 0.16 & 1.00 & \\
\hline E 40 & 3 & 3200 & 96 & C & 0.10 & 0.11 & 0.22 & 0.26 & 1.15 & \\
\hline & 4 & 3200 & 38 & A & 0.05 & 0.07 & 0.22 & 0.24 & 1.10 & \\
\hline & 5 & 3200 & 170 & $\mathrm{D}$ & 0.05 & 0.06 & 0.21 & 0.21 & 1.00 & \\
\hline & 6 & 2800 & 182 & 破断せず & 0.04 & 0.07 & 0.17 & 0.20 & 1.20 & \\
\hline E 60 & 7 & 2800 & 223 & 破断せず & 0.05 & 0.07 & 0.17 & 0.18 & 1.05 & \\
\hline & 8 & 3200 & 42 & A & 0.06 & 0.07 & 0.22 & 0.23 & 1.05 & \\
\hline & 1 & 2800 & 125 & A & 0.06 & 0.07 & 0.18 & 0.18 & 1.00 & \\
\hline E 40 & 2 & 2800 & 66 & A & 0.07 & 0.08 & 0.19 & 0.23 & 1.20 & \\
\hline & 3 & 3200 & 43 & $\mathrm{~B}$ & 0.04 & 0.06 & 0.19 & 0.20 & 1.05 & \\
\hline & 4 & 2400 & 180 & 破断せず & 0.03 & 0.04 & 0.15 & 0.16 & 1.10 & \\
\hline F $\quad 35$ & 5 & 2800 & 162 & $\mathrm{C}$ & 0.04 & 0.05 & 0.18 & 0.18 & 1.00 & \\
\hline & 6 & 3200 & 48 & $\mathrm{~B}$ & 0.06 & 0.08 & 0.18 & 0.22 & 1.25 & \\
\hline & 1 & 2400 & 188 & 破断せず & 0.04 & 0.05 & 0.13 & 0.15 & 1.20 & \\
\hline G 40 & 2 & 2800 & 55 & B & 0.05 & 0.06 & 0.17 & 0.18 & 1.05 & \\
\hline & 3 & 2800 & 53 & A. & 0.07 & 0.06 & 0.18 & 0.19 & 1.05 & \\
\hline & 4 & 3200 & 40 & B & 0.06 & 0.07 & 0.22 & 0.21 & 0.95 & \\
\hline & 1 & 2400 & 205 & 破断せず & 0.03 & 0.04 & 0.12 & 0.13 & 1.05 & \\
\hline & 2 & 2800 & 41 & $\mathrm{C}$ & 0.04 & 0.06 & 0.19 & 0.19 & 1.00 & \\
\hline H 40 & 3 & 2800 & 43 & A & 0.04 & 0.06 & 0.16 & 0.17 & 1.05 & \\
\hline & 4 & 3200 & 22 & A & 0.05 & 0.06 & 0.20 & 0.22 & 1.10 & \\
\hline
\end{tabular}

* 鉄筋破断箇所の表示はつぎのようである。

\begin{tabular}{|c|c|c|}
\hline 備 & $\begin{array}{l}\mathrm{A}: \text { :最大幅のひびわれ位置 } \\
\mathrm{C}: \text { 平均幅以下のひびわれ位置 }\end{array}$ & $\begin{array}{l}\mathrm{B} \text { : 最大幅ではないが平均幅よりは大きいひびわれの位置 } \\
\mathrm{D}: \text { ひびわれとひびわれの中間 }\end{array}$ \\
\hline
\end{tabular}


表一5 疲 労 試 験 結 果 (鉄筋直径 $25 \mathrm{~mm}$ の場合)

\begin{tabular}{|c|c|c|c|c|c|c|c|c|c|c|}
\hline \multirow{3}{*}{ 鉄筋の種類 } & \multirow{3}{*}{ 番 号 } & \multirow{3}{*}{$\begin{array}{c}\text { 上限荷重作用 } \\
\text { 時に筇志力度 } \\
\text { 鉄筋势 } \\
\left(\mathrm{kg} / \mathrm{cm}^{2}\right)\end{array}$} & \multirow{3}{*}{$\begin{array}{l}\text { 載荷回数 } \\
\left(\times 10^{4}\right) \\
\end{array}$} & \multirow{3}{*}{ 破断箇所* } & \multirow{2}{*}{\multicolumn{4}{|c|}{\begin{tabular}{c|l} 
最 大ひびわ れ 幅 $(\mathrm{mm})$ \\
荷重を除去した時 & 上限荷重が作用した時
\end{tabular}}} & \multirow{3}{*}{$\mathrm{W}_{2} / \mathrm{W}_{1}$} & \multirow{3}{*}{$\begin{array}{l}\text { 鉄筋端における } \\
\text { フックの有無 }\end{array}$} \\
\hline & & & & & & & & & & \\
\hline & & & & & 1 回目 & 10 万回後 & 1 回 $^{\mathrm{W}_{1}}$ & $\begin{array}{c}10 \text { 万回後 } \\
\mathrm{W}_{2}\end{array}$ & & \\
\hline \multirow{2}{*}{ B 30} & 1 & 2000 & 190 & 破断せず & 0.05 & 0.08 & 0.18 & 0.21 & 1.15 & \\
\hline & 2 & 2400 & 37 & A & 0.07 & 0.09 & .0 .24 & 0.27 & 1.10 & \\
\hline \multirow{3}{*}{$\mathrm{C}_{2} 40$} & 1 & 2800 & 235 & 破断せず & 0.06 & 0.10 & 0.24 & 0.29 & 1.20 & \\
\hline & 2 & 3200 & 260 & 破断せず & 0.06 & 0.09 & 0.25 & 0.28 & 1.10 & \\
\hline & 3 & 3200 & 200 & 破断せず & 0.07 & 0.12 & 0.32 & 0.36 & 1.15 & \\
\hline \multirow{2}{*}{$\mathrm{C}_{3} 35$} & 1 & 2800 & 285 & 破断せず & 0.08 & 0.16 & 0.33 & 0.45 & 1.35 & 有 \\
\hline & 2 & 3000 & 134 & B & 0.09 & 0.18 & 0.33 & 0.53 & 1.60 & 有 \\
\hline \multirow{2}{*}{ E 40} & 1 & 2800 & 280 & 破断せず & 0.06 & 0.08 & 0.22 & 0.26 & 1.15 & 有 \\
\hline & 2 & 3000 & 92 & B & 0.06 & 0.09 & 0.25 & 0.27 & 1.10 & 有 \\
\hline \multirow{2}{*}{ F 40} & 1 & 2800 & 70 & B & 0.06 & 0.11 & 0.24 & 0.31 & 1.30 & \\
\hline & 2 & 2800 & 81 & A & 0.05 & 0.12 & 0.25 & 0.29 & 1.15 & \\
\hline \multirow{2}{*}{ G 40} & 1 & 2400 & 168 & B & 0.05 & 0.12 & 0.21 & 0.29 & 1.40 & \\
\hline & 2 & 2800 & 45 & B & 0.05 & 0.08 & 0.24 & 0.25 & 1.05 & \\
\hline \multirow{3}{*}{$\mathrm{I}_{1} \quad 40$} & 1 & 2400 & 50 & A & 0.07 & 0.12 & 0.25 & 0.29 & 1.15 & \\
\hline & 2 & 2400 & 32 & A & 0.06 & 0.08 & 0.24 & 0.27 & 1.10 & \\
\hline & 3 & 2800 & 30 & B & 0.06 & 0.08 & 0.20 & 0.25 & 1.25 & \\
\hline \multirow{4}{*}{$\mathrm{I}_{2} \quad 40$} & 1 & 2400 & 155 & A & 0.06 & 0.12 & 0.24 & 0.33 & 1.35 & \\
\hline & 2 & 2800 & 234 & 破断せず & 0.07 & 0.12 & 0.26 & 0.34 & 1.30 & \\
\hline & 3 & 3000 & 225 & 破断せず & 0.07 & 0.10 & 0.30 & 0.33 & 1.10 & \\
\hline & 4 & 3200 & 55 & A & 0.05 & 0.16 & 0.23 & 0.42 & 1.80 & \\
\hline \multirow{3}{*}{$I_{3} 40$} & 1 & 2800 & 235 & $\mathrm{D}$ & 0.07 & 0.14 & 0.25 & 0.40 & 1.60 & \\
\hline & 2 & 3200 & 73 & A & 0.07 & 0.13 & 0.26 & 0.35 & 1.35 & \\
\hline & 3 & 3200 & 47 & A & 0.08 & 0.14 & 0.27 & 0.40 & 1.50 & \\
\hline \multirow{4}{*}{ J 40} & 1 & 2800 & 30 & A & 0.12 & 0.20 & 0.31 & 0.44 & 1.40 & \\
\hline & 2 & 2800 & 195 & 破断せず & 0.12 & 0.22 & 0.40 & 0.59 & 1.50 & 有 \\
\hline & 3 & 3000 & 77 & C & 0.08 & 0.16 & 0.29 & 0.47 & 1.60 & 有 \\
\hline & 4 & 3200 & 21 & A & 0.12 & - & 0.38 & - & - & \\
\hline
\end{tabular}



表一6 各種高強度異形鉄筋の疲労強度

(下限応力度 $400 \mathrm{~kg} / \mathrm{cm}^{2}$ の場合の上限応力度の值)

\begin{tabular}{|c|c|c|c|}
\hline \multirow{2}{*}{\multicolumn{2}{|c|}{ 鉄筋の種類 }} & 200 万 回疲 & 强度 $\left(\mathrm{kg} / \mathrm{cm}^{2}\right)$ \\
\hline & & 直径 $19 \mathrm{~mm}$ の場合 & 直径 $25 \mathrm{~mm}$ の場合 \\
\hline B & 30 & 2300 & 2100 \\
\hline $\mathrm{C}_{1}$ & 35 & 2600 & - \\
\hline $\mathrm{C}_{1}$ & 40 & 2600 & - \\
\hline $\mathrm{C}_{1}$ & 50 & 2500 & - \\
\hline $\mathrm{C}_{2}$ & 40 & - & 3200 以上 \\
\hline $\mathrm{C}_{3}$ & 35 & - & $2900^{*}$ \\
\hline $\mathrm{C}_{3}$ & 40 & 3000 & - \\
\hline D & 40 & $3100^{*}$ & - \\
\hline$E$ & 40 & 3000 & $2900^{*}$ \\
\hline $\mathrm{E}$ & 60 & 2900 & - \\
\hline $\mathrm{F}$ & 35 & 2700 & - \\
\hline $\mathrm{F}$ & 40 & 2600 & 2500 \\
\hline G & 40 & 2500 & 2300 \\
\hline $\mathrm{H}$ & 40 & 2400 & - \\
\hline$I_{1}$ & 40 & - & 2100 \\
\hline $\mathrm{I}_{2}$ & 40 & - & 2900 \\
\hline $\mathrm{I}_{3}$ & 40 & - & 2900 \\
\hline $\mathrm{J}$ & 40 & - & $2300,2800^{*}$ \\
\hline
\end{tabular}

*印は鉄筋端にフックを設けたものにおける值

第 2 グループは,200 万回疲労強度が $2600 \mathrm{~kg} / \mathrm{cm}^{2}$ 前 後のものであって,このグループに属する鉄筋は $\mathrm{C}_{1} 35$, $\mathrm{C}_{1} 40, \mathrm{~F} 35, \mathrm{~F} 40$ の 4 種である。これらはいずれも斜

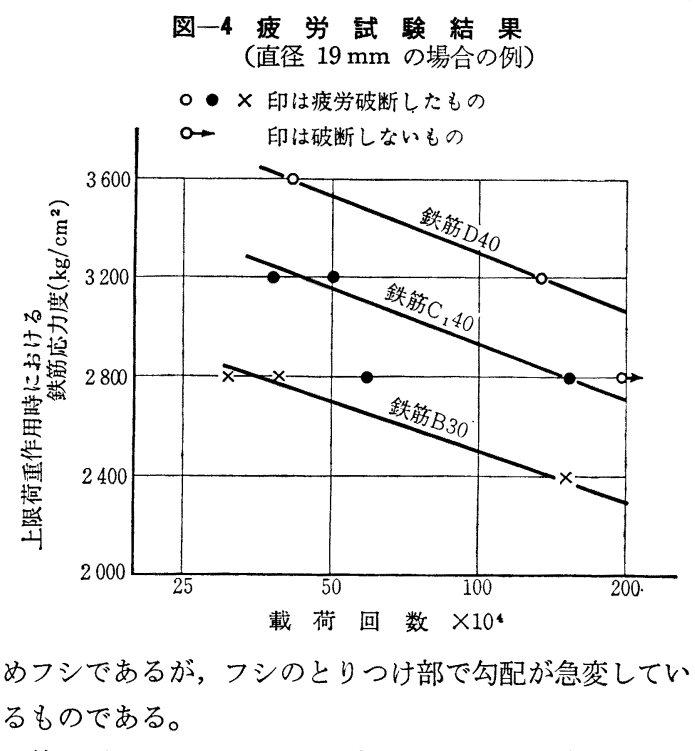

第 3 グループは,200 万回疲労強度が $2500 \mathrm{~kg} / \mathrm{cm}^{2}$ 以 下のものであって，このグループに属する鉄筋は B 30, $\mathrm{C}_{1} 50, \mathrm{G} 40, \mathrm{H} 40, \mathrm{I}_{1} 40, \mathrm{~J} 40$ の 6 種である。B 30, $\mathrm{G}^{\circ} 40$ および $\mathrm{H} 40$ は直角フシであるが，他はいずれも 斜めフシである。これらは J 40 を除いては,いずれもフ 
写真一3 鉄筋の疲労破断 位置
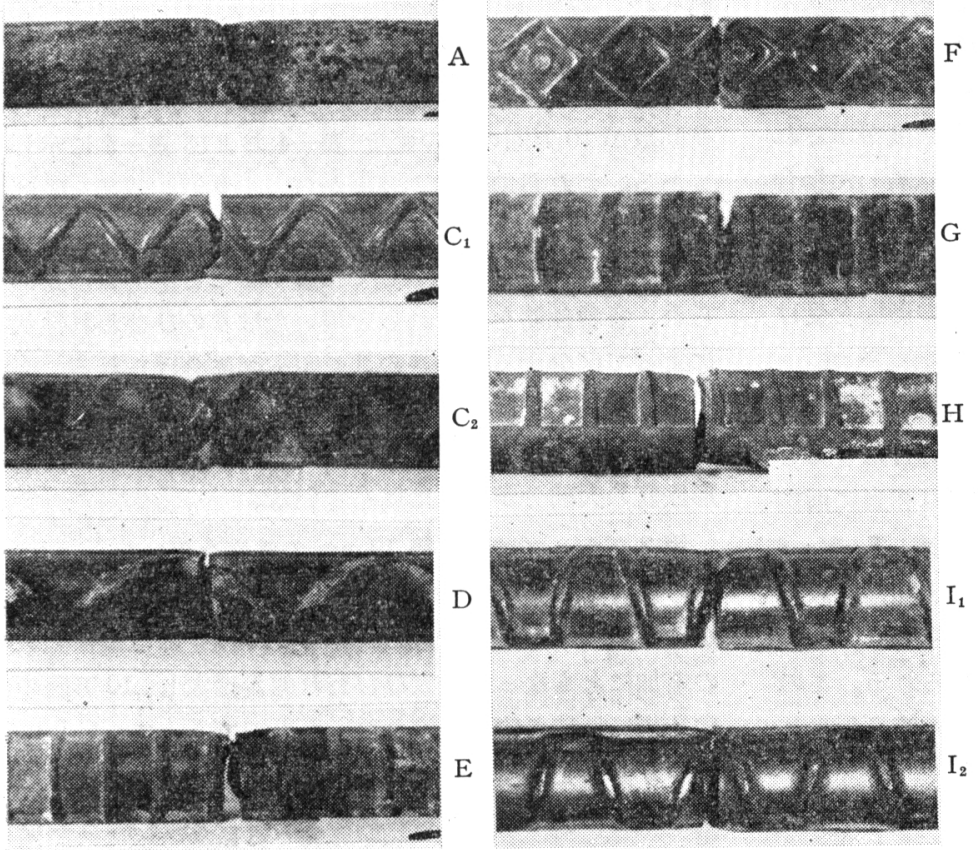

\section{$\mathrm{E}$}

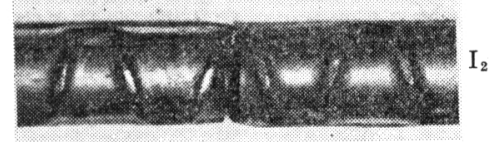

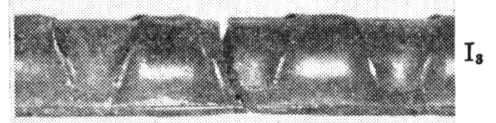

\section{G}
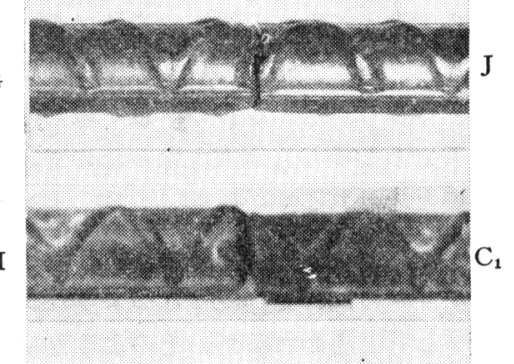

$I_{1}$

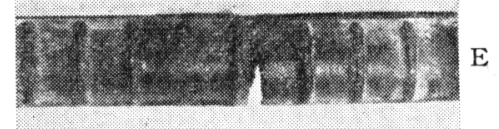

$\mathrm{I}_{2}$



シのとりつけ部で勾配が急変しているものである。 試験に用いた 18 種の異形鉄筋は,材質に大差のあるも のを子くみ,たとえば降伏点は $3000 〜 6100 \mathrm{~kg} / \mathrm{cm}^{2}$ の範 井で相違していたが, 上記 3 グループの区分は鉄筋の材 質にほとんど無関係となっている。鉄筋直径の相違によ る影響はある程度まで認められたが, 疲労強度の相違す る主要原因がフシのとりつけ部における勾配の緩急に在 ることはきわめて明瞭である。写真一3 に示すように, 直角フシの異形鉄筋の場合の疲労破断は, いずれもフシ のとりつけ部に沿って生じており, 斜めフシの場合でも フシとリブとの交点ではフシのとりつけ部から破断して いた。これは異形鉄䈘のフシのとりつけ部に応力集中が 起こり，この部分が疲労走受ける場合の弱点になること を示すものである。フシのとりつけ部の勾配を緩くすれ ば，応力集中の程度が弱められ，鉄筋の疲労強度が高く なるものと思われる。また, 鉄筋の両側でフシの位置を いくぶんずらすこと, フシと鉄筋軸とのなす角度を小さ くすること, 等も弱点を一断面に集つめないことになる ので, 疲労性状の改善に有効であろう。しかし異形鉄筋 の疲労強度を高めるには, フシと鉄筋軸とのなす角度を 小さくするよりも, フシのとりつけを適当な円孤で行な 、勾配の急変を避けることがいっそら有効である。これ は第 1 グループに属する鉄筋によって実証されている。

第 3 グループに属する異形鉄筋の大部分は研究途上の 試作品であって, 現在代表的な鉄鋼会社から市販されて いる異形鉄筋の大部分は, 第 1 グループまたは第 2 グル ープに属している。1〜2の市販品で第 3 グループに属す
るものもあるが,現在その改良が進行中であるか, または 疲労が対象となる場合には市販されないと聞いている。

したがって,これら一流会社の市販品に対しては,この 試験方法による場合の 200 万回疲労強度として, 2500 $\mathrm{kg} / \mathrm{cm}^{2}$ 以上を期待できるものと思われる。しかし，鉄 筋の疲労強度は, 鉄筋の直径, 部材の断面寸法, 試験方法, 等によって相違するものであり, 特に応力の交番が起こ る場合には, 上記試験值と相当に異なった疲労性状を呈 することもあろう。なおこの試験の試験值はある程度ば らついており, 特に第 1 グループに属するもののばらつ きは幾分大きくなっていた。したがって，疲労の影響を 受ける部材の設計における許容応力度を定める場合に は, 適当な安全度を考慮する必要がある。また, 鉄筋直 径が $19 \mathrm{~mm}$ の場合にくらべて, $25 \mathrm{~mm}$ の場合には疲労 の影響がいくぶんいちじるしくなることも示されている ので, 大径の異形鉄筋に対しては直径の影響も無視でき ない。これらをすべて考慮しても, 疲労の影響を受ける 部材に用いる高強度異形鉄筋の許容引張応力度として は, 一般に $2000 \mathrm{~kg} / \mathrm{cm}^{2}$ 程度までは十分に採り得るも のと思われる。

前記のように,フシのとりつけ部の勾配をゆるくした り, フシと鉄筋軸とのなす角度を小さく改めたりすれ ば, 鉄筋の疲労強度は高められるが, その反面, 付着強度 は低下する。したがって, これらの改善には実用上の限 度があり，異形鉄筋の選択に当っては，疲労と付着の両 性状について詳細に検討しなければならない。普通丸鋼 は耐疲労性が最も良いといわれているが，この試験にお 
ける疲労強度は, フックを設けて用いたのにもかかわら ず，第 1 グループに属する鉄筋より小さかった。また $\mathrm{J} 40$ はフシのとりつけ部の勾配がきわめてゆるやかな 鉄筋であって，両端にフックを設けて試験した場合には 第 1 グループに属するものと同程度の疲労強度が示され たものである。しかしフックを設けないで試験した場合 には第 3 グループに属してしまった。これらは付着性能 が悪いため, はりのひびわれ幅が載荷回数の増加にとも なっていちじるしく過大となったので，その影響を受け たものと思われる。

鉄筋の疲労強度を検討する場合には，破断までの載荷 回数が 200 万回程度以上となるような試験を行なうこと が望ましいと思われるが，そのような試験は相当に面倒 であり, 試験に要する時間も長い。表一 4 , 表一 5 , 表一6 を通覧すると, 破断までの載荷回数が 100 万回程度以上 となるような試験を行なえば, その結果から200万回疲 労強度が相当正確に推定できることが認められる。この ようにすることによって疲労試験もいくぶん簡易化され る。

\section{（2）ひびわれ性状}

鉄筋コンクリート部材においては，コンクリートに生 ずるひびわれの幅が過大となると, 鉄筋が腐食して部材 の耐久性を損なうおそれがあるので，特に高強度の鉄筋 を用いる場合には, その許容引張応力度をひびわれ幅を 考慮して制限する必要も考えられる。そこで鉄筋コンク リートばりの疲労試験に当って, コンクリートに生ずる ひびわれの幅を測定し, 異形鉄筋の相違がくり返し載荷

図一5＼cjkstart鉄筋の相違がはりのひびわれ性状におよぼす影響 （鉄筋直径 $25 \mathrm{~mm}$, 上限荷重作用時における鉄節 の応力度 $2800 \mathrm{~kg} / \mathrm{cm}^{2}$ の場合の例)

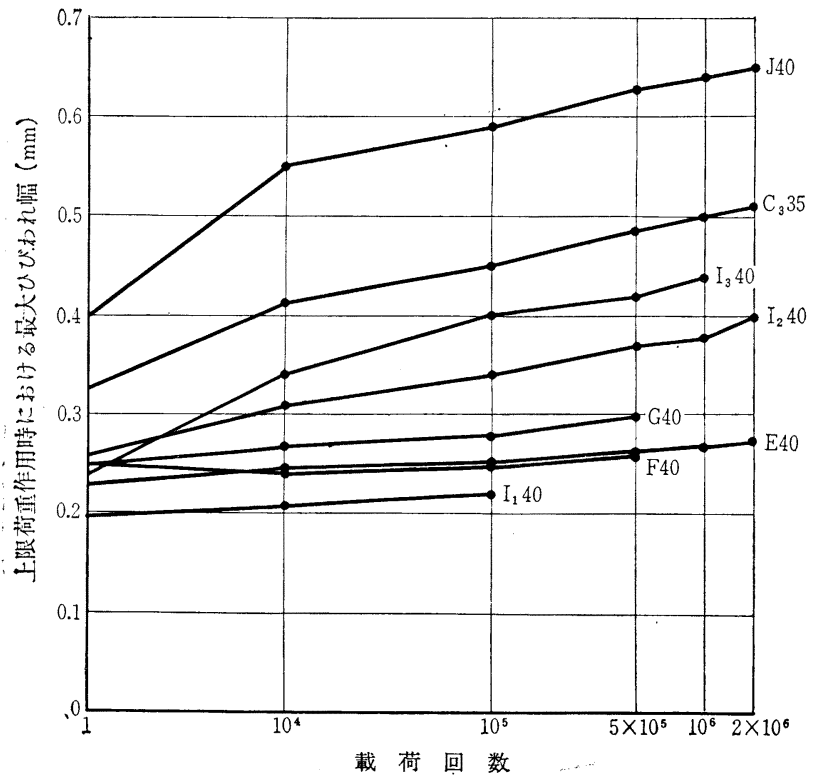

を受けるはりのひびわれ性状におよぼす影響について検 討した。

最大ひびわれ幅の試験結果の一例は図一 5 に示すよう であり,すべてのはりについての疲労試験開始直前と載 荷回数が 10 万回の時の值を 表一 4 および 表一5 に示し てある。これらの図および表から，くり返し載荷を受け る鉄筋コンクリートばりのひびわれ性状が，用いる鉄筋 の種類によっていちじるしく相違することが明瞭に認め られ，各種鉄筋を，それらを用いたはりのひびわれ性状 によって区分するとつぎの 3 グルーブに分けられる。

第 1 グループは，くり返し載荷を受けてもはりの最大 ひびわれ幅がほとんど増大しなかったもので, 用いた異 形鉄筋の大部分がこれに属している。

第 2 グループは, 直径 $19 \mathrm{~mm}$ の鉄筋を用いた $\mathrm{T}$ 型ば りの場合には最大ひびわれ幅がほとんど増大しなかった が，直径 $25 \mathrm{~mm}$ を用いた矩形ばりの場合には載荷回数 の増加にともなって最大ひびわれ幅が増大し, 10 万回の 載荷時に最初の約 1.5 倍となったものであって, $\mathrm{C}_{3}, \mathrm{I}_{3}$, $\mathrm{J}$ の 3 種がこれに属している。これらはいずれも JIS の 規定に適合する斜めフシの異形鉄筋で, フシのとりつけ 部にはフシの高さの 5 倍以上の半径をもつ円孤を設けた ものである。

第 3 グループは, 直径 $19 \mathrm{~mm}$ の鉄筋を用いた T 型ば りの場合にも，載荷回数の増加にともなって最大ひびわ れ幅がいちじるしく増大したもので，A，Dの 2 種がこ れに属している。A は普通丸鋼であり，D は JIS の規 定に適合しないきわめてデフォーメーションの少ない異

\section{表一7 引拔き試験における各 種鉄筋の付着強度 ${ }^{2)}$}

自由端における鉄筋の滑動量が (0.1 mm に達した時の平均付着 応力度を, 鉄筋 G 40 を 100 と して表わしたものである。

\begin{tabular}{|c|c|}
\hline 鉄筋の種類 & 付着強度の比 \\
\hline A 30 & 31 \\
\hline B 30 & 102 \\
\hline $\mathrm{C}_{2} 40$ & 86 \\
\hline $\mathrm{C}_{3} 40$ & 80 \\
\hline D 40 & 64 \\
\hline E 40 & 112 \\
\hline F 40 & 86 \\
\hline G 40 & 100 \\
\hline $\mathrm{I}_{1} \quad 40$ & 93 \\
\hline $\mathrm{I}_{2} \quad 40$ & 100 \\
\hline$I_{3} \quad 40$ & 82 \\
\hline $\mathrm{J} \quad 40$ & 74 \\
\hline
\end{tabular}

形鉄筋である。

このようにはりの ひびわれ性状が用い る鉄筋の種類によっ て異なるのは，その 付着性能が相違する からである。これを 確かめるため，表一 7 の付着強度試験結 果と対比してみると つぎのようになる。 表一7 は引抜き試験 によって求めた各鉄 筋の付着強度を鉄筋 $\mathrm{G}$ の付着強度を 100 。 として表わしたもの

であるが，第 1 グループに属する鉄筋は 86 以上， 第 2 グループに属するものは 74〜82, 第 3 グル ープに属するものは 65 以下であって，上記の論 旨と一致している。したがって，鉄筋コンクリー トばりによる疲労試験を行なえば, 異形鉄筋の疲 
労性と同時に付着性をも判定できるのであって，付着強 度試験を追加する必要はないと思われる。

異形鉄筋において，フシと鉄笳軸とのなす角度を小さ くすること・フシのすきまを大きくすること・フシのとり つけ部の勾配をゆるくすること・等はいずれも耐疲労性 の改善には有利であるが, 付着性能を低下させるもので あって,これらの要素が重なれば付着性能はいちじるし く劣り, はりのひびわれ性状にも悪影響をおよぼすこと がある。したがって, 疲労および付着の両性状を考慮すれ ば,フシのとりつけ部における円孤の適当な半径は, フ シと鉄筋軸とのなす角度, フシの高さその他によっても 若干相違するが, 一般にフシの高さの 1 2 倍程度であ 万う。

\section{4. 異形鉄筋における応力集中}

3. で述べたごとく, 各種異形鉄筋において 疲労強度 が相違する主要原因は, フシとりつけ部の勾配の緩急で あり, 延いてはこの部分における応力集中の差によるも のと思われた。これをさらに確かめるため, フシとりつ け部の勾配が異なる各種異形鉄筋について, フシの近傍 における応力分布を測定し検討を加えた。

\section{図一6引張試験におけるゲージ貼りつけ位置} 搪大図
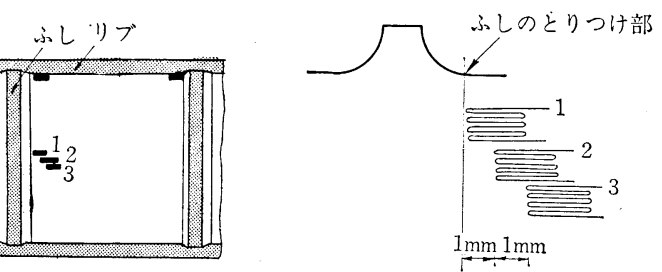

搪大図
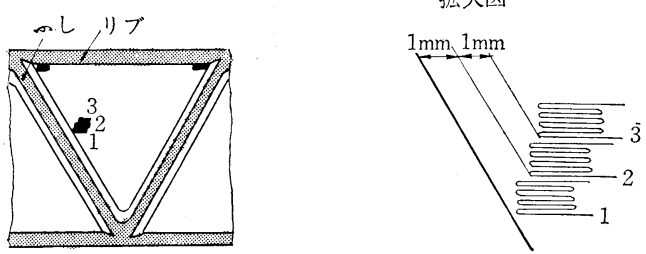

表一8 異形鉄筋における応力集中度

(鉄筋直径 $25 \mathrm{~mm}$, 鉄筋応力度 $2400 \mathrm{~kg} / \mathrm{cm}^{2}$ の場合の值を, フンのと りつけ部から $3 \mathrm{~mm}$ 離れた点における央测值を100として表わしたも のである。

\begin{tabular}{|c|c|c|c|c|c|c|}
\hline \multirow{2}{*}{ 鉄筋の種類 } & \multicolumn{2}{|c|}{ 応 } & 集 & \multicolumn{2}{|c|}{ 度* } & \multirow{2}{*}{$\sigma_{0} / \sigma_{1}$} \\
\hline & $\sigma_{2}$ & $\sigma_{1}$ & $\sigma_{0}$ & $\sigma_{1 \max }$ & $\sigma_{0} \max$ & \\
\hline B 30 & 102 & 115 & 128 & 127 & 141 & 1.20 \\
\hline $\mathrm{C}_{3} 40$ & 102 & 105 & 108 & 112 & 115 & 1.03 \\
\hline E 40 & 105 & 115 & 125 & 134 & 147 & 1.09 \\
\hline F 40 & 108 & 114 & 120 & 131 & 138 & 1.09 \\
\hline G $\quad 40$ & 104 & 117 & 130 & 128 & 142 & 1.11 \\
\hline $\begin{array}{ll}\mathrm{I}_{2} & 40\end{array}$ & 106 & 115 & 124 & 120 & 129 & 1.08 \\
\hline $\begin{array}{ll}\mathrm{I}_{3} & 40\end{array}$ & 104 & 107 & 110 & 117 & 120 & 1.03 \\
\hline $\mathrm{J} \quad 40$ & 104 & 106 & 108 & 107 & 109 & 1.02 \\
\hline
\end{tabular}

*応力集中度の表示はつぎのようである。

備 $\sigma_{2}$ : フンのとりつけ部から $2 \mathrm{~mm}$ 離れた点におけろ実測值 $\sigma_{1}:$ フンのとりつけ部から $1 \mathrm{~mm}$ 離れた点における実測值 $\sigma_{0}: \sigma_{2}$ と $\sigma_{1}$ を結んで延長し,フンのとりつけ部に岕ける值 を推定したもの

$\sigma_{1 \text { max }}$ :フンとリブとの交差している点でフンのとりつけ部から $1 \mathrm{~mm}$ 離れた点における実测值 $\sigma_{0 \max }: \begin{aligned} & \sigma_{1} \max に \sigma_{0} / 1 \sigma \text { 乗して求めたもので,フンとリブとの } \\ & \text { 交差している点におる推定値 }\end{aligned}$

8 種の異形鉄筋について， ゲージ長 $2 \mathrm{~mm}$ のワイヤ ストレィン ゲージをフシとりつけ部に接して 1 枚, そ こから $1 \mathrm{~mm}$ ずつずらしてさらに 2 枚, 合計 3 枚, 貼り つけて引張試験を行なった(図一6 参照)。試験結果の 例は図一7に示すようであって,フシのとりつけ部近傍 の応力集中が特にいちじるしいことが認められる。これ らの実測值は $2 \mathrm{~mm}$ の間の平均值に過ぎないので, とり つけ部には，さらに大きな応力集中が㗢いていることが 考えられる。実測值の 3 点を結んで延長し, フシとりつ け部における応力集中度を推定した。なお応力集中度は, とりつけ部から $3 \mathrm{~mm}$ 離れた所 (フシの影響を受けない と考えられる) の応力度を 100 として表わすこととし た。その結果は 表一8 に示すようであり，この応力集中度 $\left(\sigma_{0}\right)$ は鉄筋によって異なった。すなわち, 鉄筋 Bおよび $\mathrm{G}$ は $130, \mathrm{E}, \mathrm{F}, \mathrm{I}_{2}$ は $120 \sim 125, \mathrm{C}_{3}, \mathrm{I}_{3}, \mathrm{~J}$ は 110 程度とな った。これらの值はリブから十分に離れた部分における もので，フシとリブとの交差している部分ではさらに大 きいと思われる。そこで,リブから離れた部分における推 定值と実測值との比を, フシとリブとの交差している部 分における実測值に乗じて, この部分における応力集中 度を推定してみた。それ らの推定值 $\left(\sigma_{0} \max \right)$ は表 -8 に示すごとく, 鉄筋 B, E, F, G は 140〜150, $\mathrm{I}_{2}$ は $130, \mathrm{I}_{3}, \mathrm{C}_{3}, \mathrm{~J}$ は 110 〜120であった。 $\mathrm{B}, \mathrm{E}$, $\mathrm{G}$ は直角フシ, 他は斜め フシで, $\mathrm{C}_{3}, \mathrm{E}, \mathrm{I}_{2}, \mathrm{I}_{3}, \mathrm{~J}$ 等はとりつけ部に円孤を 設けたものである。特に $\mathrm{C}_{3}, \mathrm{I}_{3}, \mathrm{~J}$ は円孤の半径を 
大きくとったものである。これらは, 異形鉄筋のフシの とりつけ部における応力集中の程度は, フシと鉄筋軸と のなす角度によってもいくぶん異なるが，フシのとりっ け部の緩急によっていちじるしく相違することを明瞭に 示すものであり，3．の論旨を実証するものである。

これらの試験において応力集中度が 130 以下である鉄 筋はすべて疲労強度の最も高い第 1 グループ (3. 参照) に属している。したがって鉄筋の引張試験を行ない，フ シとりつけ部に働く応力集中を測定することによって, ある程度まで異形鉄筋の疲労強度が推定できることが示 唆されていると思われるが，応力集中測定方法の細部に ついてはいっそうの研究が必要である。

鉄筋の疲労破断位置とコンクリートに生じたひびわれ の位置との関係を検討すると，表一4 および 表一5 亿示 してあるように, 最大幅に近いひびわれの位置と一致し ているもの（A） $57 \%$ ，最大幅ではないが平均幅以上の ひびわれの位置と一致しているもの（B） $29 \%$ であっ て、ひびわれの中間で破断したもの (D) はわずか $3 \%$ に過ぎなかった。ここでひびわれの位置と一致したと表 現した中にはひびわれの位置から $1 \mathrm{~cm}$ 以内における場 合をもふくめているのであるが，これらの結果はひびわ れの位置における鉄筋の引張応力度が他の部分よりも相 当に大きくなっていたことによると思われる。

これらをさらに確かめるため, 図一8に示すように, 直径 $19 \mathrm{~mm}$ の鉄筋を半割りに切断し, その内部にワイ

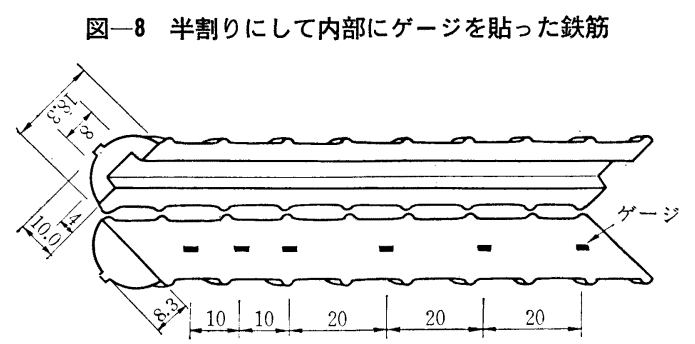

図一9 ひびわれ周辺における鉄筋の応力度

II 型

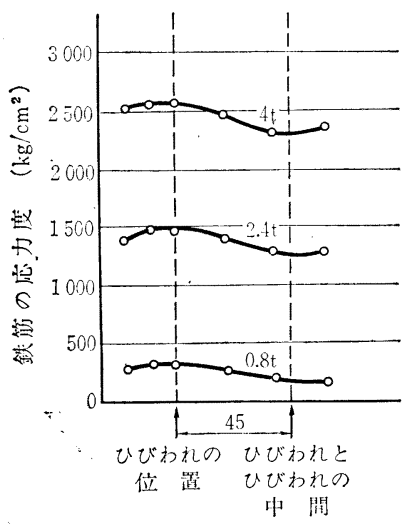

I 型

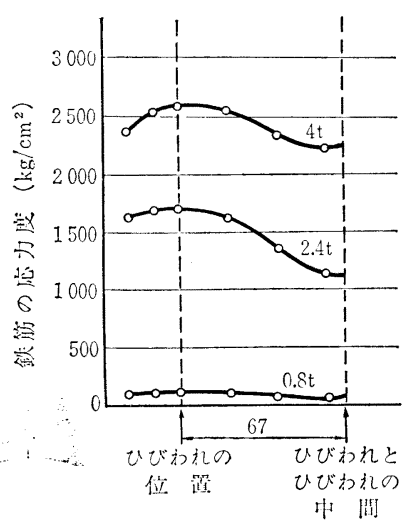

ヤ ストレィン ゲージを $10 \sim 20 \mathrm{~mm}$ 間隔に貼りつけ たのち, 鉄筋両半部を接着剤で貼り合わせ一体とした鉄 筋を用いてはりの曲げ試験を行ない，ひびわれ周辺にお ける鉄筋応力度を詳細に測定した。鉄筋を切断する場合 に中心からいくぶんずらした面で切り，ゲージの位置が 内部をくりぬいた 鉄筋断面の重心と一致するようにし た。このような鉄筋を用いたのは，鉄筋とコンクリート との付着状態を変えないで，鉄筋のひずみを測定するた めである。用いた供試体は図一10 に示すIII型( $\mathrm{T}$ 型断面) およびI 型 (矩形断面)のはり供試体で,まず静的に $4 \mathrm{t}$ まで載荷した。この際 $0.8 \mathrm{t}$ ごとに鉄筋の応力度を測定 した（鉄筋応力度の測定結果は図一9のようになった）。 その後, さらに下限荷重を $0.8 \mathrm{t}$, 上限荷重を $4 \mathrm{t}$ として 1 万回の載荷を行なった。ひびわれ周辺における鉄筋応 力度の一例は図一9に示すようであって, ひびわれの位 置で大きくひびわれとひびわれとの中間では小さくなっ ていることが明瞭に認められる。ひびわれの位置におけ る鉄筋応力度とひびわれの中間における鉄筋応力度との 差(応力差)は, 荷重の増加にともなって増大し, 鉄筋応 力度が $1000 \sim 1500 \mathrm{~kg} / \mathrm{cm}^{2}$ 程度で, $200 \sim 400 \mathrm{~kg} / \mathrm{cm}^{2}$ に達するが, その後はひびわれ幅は増大するにもかかわ らずこの応力差はほとんど増大しなかった。またくり返 し載荷によってもこの応力差はほとんど増大しなかっ た。これらのことは，ひびわれの位置で鉄筋の疲労破断 が起こりやすいのは，この位置における鉄筋応力度が他 の部分よりも大きいことが一つの原因であることを示す とともに，その他の原因，たとえばひびわれの位置では 鉄筋とコンクリートとの相対変位が大きく，そのために 異形鉄筋のフシに集中応力が働くこと—これはひびわ れの幅が大きいほどいちじるしい—等の影響が相当に 大きいことを示すものと思われる。

\section{5. 断面形状および鉄筋比の相違がはりの疲労 性状におよぼす影響}

鉄筋コンクリートばりの疲労性状は用いる 鉄筋による影響を受けるばかりでなく，断面 形状および鉄筋比による影響をも受けること が考えられる。そこで,これらを変化させて造 ったはりの疲労試験を行ない検討を加えた。

用いた供試体は 図一10に示す6種とした。 すなわち,供試体断面を同じくし,用いる鉄筋 の本数のみを $2,3,5$ 本と変化させることに よって，鉄筋比だけを $0.6,0.9,1.5 \%$ の 3 種に変化させたもの，および鉄筋比を同じく し，供試体断面を変化させることによって， かぶり厚さだけを $1,3,6 \mathrm{~cm} の 3$ 種に変化 させたものである。用いた鉄筋はいずれも F 40 である。用いたコンクリートは 表一2 
図-10供試体の形状および寸法
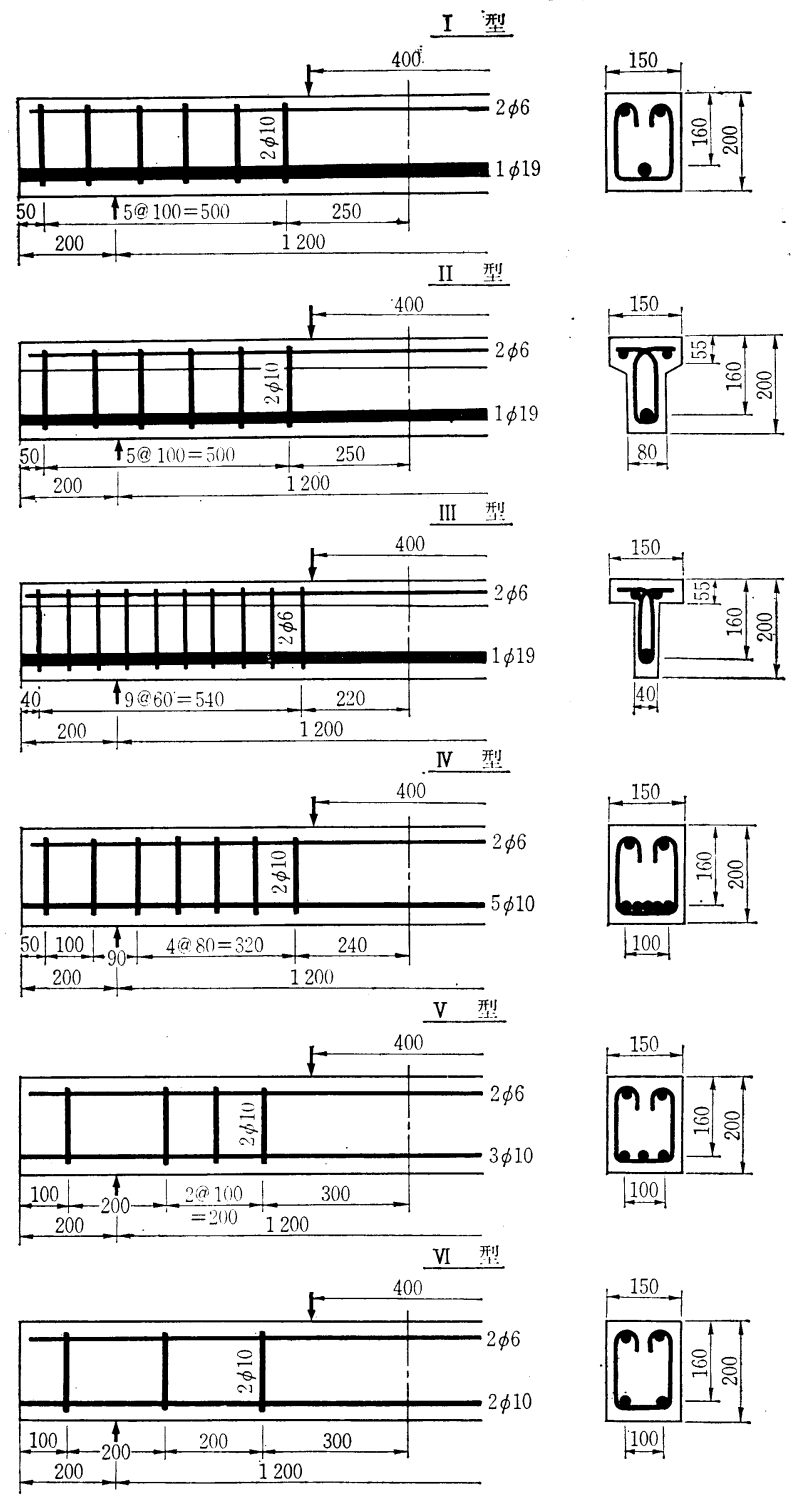

に示す配合 2 で, 粗骨材の最大寸法を $15 \mathrm{~mm}$ と した。下限荷重を鉄筋応力度が $400 \mathrm{~kg} / \mathrm{cm}^{2}$ に相 当する荷重とし, 上限荷重を $2400 \mathrm{~kg} / \mathrm{cm}^{2}$ に相 当する荷重として 45 万回載荷したのち, 上限荷 重を $3200 \mathrm{~kg} / \mathrm{cm}^{2}$ に相当する荷重まであげて続 行し破壊に至らしめた。

上限荷重を $3200 \mathrm{~kg} / \mathrm{cm}^{2}$ に相当する荷重とし てから，鉄筋が疲労破断するまでの載荷回数は表 一6のようであって，6種のはりは断面形状およ び鉄筋比が相当に異なっているが，その疲労強度 はほぼ同程度であることが認められる。これは断 面形状および鉄筋比がこの程度に相違していても 上下限における鉄筋応力度が同じくなっていたこ とによるものである。したがって，はりの疲労試 験によって異形鉄筋の疲労強度を求める場合に は，特に付着性能の劣るものでないかぎり，一般 にはりの断面形状および鉄筋比を比較的自由に選 んでもよいことになる。これは鉄筋コンクリート 部材に用いる鉄筋の疲労性状試験の簡易化に役立 つ便利な性質であろう。

また土木学会の研究グリープはスパン $4.6 \mathrm{~m}$ の大型 T型ばりによって各種異形鉄筋の疲労試験 を行なったが(10)，その試験結果も大体において， この小型ばりによる試験結果と一致していた。こ れは，小型ばりによる試験結果にもとづいて，鉄 筋コンクリート部材の疲労性状を論じ得ることを 実証したものである。

前記の疲労強度試験の場合にも，2.で述べた方 法でひびわれ幅を測定した。最大ひびわれ幅の試 験結果は表一9に示すようであって, くり返し載 荷を受けるはりのひびわれ性状におよぼす鉄筋比 の影響は小さいが, 断面形状の影響は相当に大き い。したがって, 鉄筋コンクリートばりの疲労試

表一9 疲 労試 験 結 果

\begin{tabular}{|c|c|c|c|c|c|c|c|c|c|c|c|c|}
\hline \multirow{3}{*}{ 供試体断面 } & \multirow{3}{*}{$\begin{array}{l}\text { 鉄筋直径 } \\
(\mathrm{mm})\end{array}$} & \multirow{3}{*}{$\begin{array}{c}\text { 鉄筋 比 } \\
(\%)\end{array}$} & \multirow{3}{*}{$\begin{array}{l}\text { 鉄筋の } \\
\text { がゲリ } \\
(\mathrm{mm})\end{array}$} & \multirow{3}{*}{ 番号 } & \multirow{3}{*}{$\begin{array}{l}\text { 載荷回数* } \\
\left(\times 10^{4}\right)\end{array}$} & \multicolumn{7}{|c|}{ 上限荷重作用時における最大ひびわれ幅 (mm) } \\
\hline & & & & & & \multicolumn{4}{|c|}{$\begin{array}{l}\text { 上限荷重作用時における鉄筋応力度が } \\
2400 \mathrm{~kg} / \mathrm{cm}^{2} \text { の場合 }\end{array}$} & \multicolumn{3}{|c|}{$\begin{array}{l}\text { 上限荷重作用時における鉄筋応力度が } \\
3200 \mathrm{~kg} / \mathrm{cm}^{2} \text { の場合 }\end{array}$} \\
\hline & & & & & & 1 回目 & $\begin{array}{l}\text { 載荷 } \\
1 \text { 万回後 }\end{array}$ & 10 万回後 & 45万回後 & 1 回目 & $\begin{array}{l}\text { 載荷 } \\
1 \text { 万回後 }\end{array}$ & 10万回後 \\
\hline I 型 & 19 & 1.19 & 65 & $\begin{array}{l}1 \\
2\end{array}$ & $\left.\begin{array}{l}45 \\
38\end{array}\right\} 42$ & $\begin{array}{l}0.16 \\
0.15\end{array}$ & $\begin{array}{l}0.19 \\
0.19\end{array}$ & $\begin{array}{l}0.20 \\
0.21\end{array}$ & $\begin{array}{l}0.21 \\
0.23\end{array}$ & $\begin{array}{l}0.25 \\
0.26\end{array}$ & $\begin{array}{l}0.27 \\
0.29\end{array}$ & $\begin{array}{l}0.29 \\
0.31\end{array}$ \\
\hline II 型 & 19 & 1.19 & 30 & $\begin{array}{l}1 \\
2\end{array}$ & $\left.\begin{array}{l}37 \\
34\end{array}\right\} 36$ & $\begin{array}{l}0.18 \\
0.13\end{array}$ & $\begin{array}{l}0.19 \\
0.13\end{array}$ & $\begin{array}{l}0.19 \\
0.14\end{array}$ & $\begin{array}{l}0.20 \\
0.15\end{array}$ & $\begin{array}{l}0.24 \\
0.18\end{array}$ & $\begin{array}{l}0.25 \\
0.17\end{array}$ & $\begin{array}{l}0.26 \\
0.18\end{array}$ \\
\hline III 型 & 19 & 1.19 & 10 & $\begin{array}{l}1 \\
2\end{array}$ & $\left.\begin{array}{l}37 \\
33\end{array}\right\} 35$ & $\begin{array}{l}0.13 \\
0.11\end{array}$ & $\begin{array}{l}0.15 \\
0.12\end{array}$ & $\begin{array}{l}0.15 \\
0.12\end{array}$ & $\begin{array}{l}0.15 \\
0.12\end{array}$ & $\begin{array}{l}0.19 \\
0.16\end{array}$ & $\begin{array}{l}0.19 \\
0.16\end{array}$ & $\begin{array}{l}0.20 \\
0.16\end{array}$ \\
\hline IV 型 & 10 & 1.48 & 20 & $\begin{array}{l}1 \\
2\end{array}$ & $\left.\begin{array}{l}34 \\
38\end{array}\right\} 36$ & $\begin{array}{l}0.14 \\
0.13\end{array}$ & $\begin{array}{l}0.16 \\
0.14\end{array}$ & $\begin{array}{l}0.16 \\
0.15\end{array}$ & $\begin{array}{l}0.17 \\
0.16\end{array}$ & $\begin{array}{l}0.22 \\
0.20\end{array}$ & $\begin{array}{l}0.24 \\
0.20\end{array}$ & $\begin{array}{l}0.25 \\
0.21\end{array}$ \\
\hline $\mathrm{V}$ 型 & 10 & 0.89 & 20 & $\begin{array}{l}1 \\
2\end{array}$ & $\left.\begin{array}{l}40\} \\
36\end{array}\right\}$ & $\begin{array}{l}0.11 \\
0.10\end{array}$ & $\begin{array}{l}0.13 \\
0.16\end{array}$ & $\begin{array}{l}0.14 \\
0.17\end{array}$ & $\begin{array}{l}0.14 \\
0.17\end{array}$ & $\begin{array}{l}0.18 \\
0.21\end{array}$ & $\begin{array}{l}0.19 \\
0.22\end{array}$ & $\begin{array}{l}0.19 \\
0.21\end{array}$ \\
\hline VI 型 & 10 & 0.59 & 20 & $\begin{array}{l}1 \\
2\end{array}$ & $\left.\begin{array}{l}42 \\
43\end{array}\right\} 43$ & $\begin{array}{l}0.09 \\
0.12\end{array}$ & $\begin{array}{l}0.14 \\
0.15\end{array}$ & $\begin{array}{l}0.15 \\
0.17\end{array}$ & $\begin{array}{l}0.17 \\
0.18\end{array}$ & $\begin{array}{l}0.20 \\
0.22\end{array}$ & $\begin{array}{l}0.22 \\
0.23\end{array}$ & $\begin{array}{l}0.23 \\
0.23\end{array}$ \\
\hline
\end{tabular}


験に当って，鉄筋の付着性をも判定しようとする場合に は，断面形状の影響について考慮を払う必要がある。

\section{6. 結論}

材質および形状の相違する各種高強度異形鉄筋を用い て,鉄筋コンクリートばりの曲げ疲労試験を行ない,その 疲労性状について検討した。疲労試験は, 高さ $20 \mathrm{~cm}$, 長さ $160 \mathrm{~cm}$ の鉄筋コンクリートばりについて行なった が，下限荷重を鉄筋応力度が $400 \mathrm{~kg} / \mathrm{cm}^{2}$ に相当する荷 重とし, 上限荷重を適当に定め, 載荷速度を 300 回/分 とした。試験の結果から, 載荷を 200 万回継続した時に 破壊する上限荷重を求め, これに相当する鉄筋応力度を 200 万回疲労強度と呼び，これにもとづいて各種高強度 異形鉄筋の疲労強度を論じたのである。試験に用いた異 形鉄筋は総計 18 種であって, 降伏点は $3000 \sim 6100 \mathrm{~kg} /$ $\mathrm{cm}^{2}$ の範囲で相違し, フシの形状も大差のあるものを子 くんでいる。しかし，フシの高さ・間隔・およびすきま ・等においては比較的に類似しているため, 本研究の成 果があらゆる種類の異形鉄筋に適用されるものとは限ら ないが，わが国の現在の市販品に関しては, 試験の範囲 内でつぎのことがいえると思われる。

1. 鉄筋コンクリートばりの曲げ引張疲労強度は, 用 いる鉄筋の相違によっていちじるしく異なるが，はりの 断面形状, 鉄筋の配置および鉄筋量, 等の相違による影 響は小さいことが確かめられた。たとえば，各種異形鉄 筋を用いたはりについて，下限荷重を鉄筋応力度が 400 $\mathrm{kg} / \mathrm{cm}^{2}$ に相当する荷重とし, 上限荷重を $2800 \mathrm{~kg} / \mathrm{cm}^{2}$ に相当する荷重として, 疲労試験を行なった場合には, 用いる鉄筋の種類によって, 30 万回程度の載荷で疲労 破壊するものから 200 万回以上の載荷でも疲労破壊しな いものまであった。しかし，同じ種類の鉄筋を用いた場 合には, 鉄筋比を $0.6 \%$ から $1.5 \%$ に変化させても, あるい壮断面を矩形から 型に変えても，破壊するまで の載荷回数にはほとんど相違が認められなかったのであ る。したがって, この疲労試験の結果から鉄筋の疲労強 度を論じても実用上支障ないものと信じている。

2. 高強度異形鉄筋のこの試験方法による 200 万回疲 労強度は, 用いた鉄筋の範囲内で, 高いものは $3200 \mathrm{~kg} /$ $\mathrm{cm}^{2}$ 以上にも達するが, 低いものは $2000 \mathrm{~kg} / \mathrm{cm}^{2}$ 程度に 過ぎず，鉄筋の種類によっていちじるしい相違が認めら れたが, 現在の代表的な高強度異形鉄筋は $2500 \mathrm{~kg} / \mathrm{cm}^{2}$ 以上であった。したがって, 試験方法による疲労性状の 相違, 鉄筋のばらつき, その他を考慮しても, 降伏点 が $3500 \mathrm{~kg} / \mathrm{cm}^{2}$ 以上で, JIS に合するデフォーメーショ ンを持つ高強度異形鉄筋に対しては, 疲労の影響を受け る部材に用いる場合の許容引張応力度として, 一般には $2000 \mathrm{~kg} / \mathrm{cm}^{2}$ 程度の值を採っても実用上支障ないものと 思われる。
3. 各種異形鉄筋において, 疲労強度が相違する主要 原因は，フシが鉄筋表面にとりつく取りつけ部の勾配の 緩急にあり，延いてはこの部分における応力集中の差に よるものであって, フシとりつけ部を適当な円孤として 応力集中を緩和したものの耐疲労性はきわめて良好であ る。すなわち，異形鉄筋でもフシとりつけ部をフシの高 さの 1 9 倍の半径をもつ円孤としたものの 200 万回疲 労強度はいずれも $2800 \mathrm{~kg} / \mathrm{cm}^{2}$ 以上であった。また 200 万回疲労強度が $2100 \mathrm{~kg} / \mathrm{cm}^{2}$ 程度の鉄筋において, フ シとりつけ部だけを変え, フシの高さの 2 倍あるいは 5 倍の半径をもつ円孤に改めた鉄筋は, その 200 万回疲労 強度がいずれも $2900 \mathrm{~kg} / \mathrm{cm}^{2}$ 程度となっていちじるし く改善された。このように, フシとりつけ部の勾配をゆ るくすれば疲労性状はいちじるしく改善されるが, 付着 性状は劣ってくる。それで付着性状をも考慮すると, 適 当な円孤の半径としては, フシの高さ・フシと鉄筋軸と のなす角度・等によって若干の相違はあるが，一般にフ シの高さの 1 2 倍であろう。なお, 異形鉄筋に捛いて, フシと鉄筋軸とのなす角度を小さくすればいくぶん耐疲 労性は高められるが，これは疲労に対する弱点であるフ シ取りつけ部が一断面に集まらないことによるものと思 われる。このように, 高強度異形鉄筋の疲労強度におよ ぼすフシ形状の影響はきわめて大きいが，その材質の影 響は，実験の範囲内ではほとんど認められなかった。

4. くり返し載荷を受ける鉄筋コンクリートばりのひ びわれ性状は,鉄筋の付着性状の影響を受け,その影響の 程度は, 静的載荷を受ける場合よりいちじるしいことが 認められた。付着の良好な異形鉄筋を適当に用いれば過 大なひびわれの発生を防止することができるが，JIS の デフォーメーションの規定の範囲内にある異形鉄筋であ っても，付着を悪くするような諸条件，すなわちフシと 鉄筋軸とのなす角度が小さいこと・フシのとりつけ部そ の他が余りに滑めらかであること・フシの高さが小さい こと・等が重なった鉄筋を用いる場合には，はりのひび われは載荷回数の増加にともなっていちじるしく過大と なり，耐久性に支障をきたす場合がある。本試験におい ても，この種の異形鉄筋や普通丸鋼を用いたはりにおい て, 過大となったひびわれによってはりが早期に疲労破 断した事例があった。しかし, 現在市販されている代表 的な高強度異形鉄筋は，一般に規格に十分適合するもの でありこれれを用いたときのはりのひびわれ幅は,く り返し載荷を受けてもほとんど増大しなかった。

5. 鉄筋コンクリートばりによる鉄筋の疲労試験には， 小型ばりを用いても実物大の部材における疲労性状をあ る程度まで推定できること, 異形鉄筋の疲労および付着 の両性状を同時に判定できること，等の特長があるの で, 鉄筋の引張疲労試験および曲げ疲労試験より合理的 であると思われる。しかし，この種の試験には特別の機 
械を必要とし, 試験に要する時間も多く相当に面倒であ ることが久点である。はりにおけるる鉄筋の疲労破断が応 力集中によるものであることを考慮すれば，鉄筋表面に ゲージ長の短いワイヤ ストレィン ゲージを多数貼りつ けて引張試験し，フシとりつけ部近傍の応力集中を測定 することによって，簡便に異形鉄筋の耐疲労性をある程 度まで推定できることが認められた。

\section{参 考 文 献}

1）丸安隆和・吉谷 豊・小林一輔：冷間ねじり鉄筋の疲労試 験結果について, コンクリート・ライブラリー第 2 号, 昭和 37 年 12 月

2）横道英雄・藤田嘉夫：各種異形鉄笳を用いた鉄筋コンク リート桁の曲げ試験について, コンクリート・ライブラ リ一第 2 号, 昭和 37 年 12 月

3）河野通之 - 富田勝信 - 小松原政次 - 渡辺信一 - 小寺重郎 : 異形鉄筋の疲れ強度に関する研究, コンクリート・ライ ブラリー第 2 号, 昭和 37 年 12 月
4）中山紀男 : 異形鉄筋を用いた鉄筋コンクリートはりの疲 労について, セメント技術年報, 昭和 38 年

5）横道英雄・太田利隆・西堀忠信：鉄筋コンクリートけた の曲げ疲労に関する実験的研究, セメント技術年報, 昭 和 38 年

6）横道英雄・藤田嘉夫・小谷一三・西堀忠信 : 鉄筋コンク リートはりの疲労に関する実験的研究, セメント技術年 報, 昭和 39 年

7) JIS G 3112 “鉄筋コンクリート用棒鋼”

8）国分正胤・後藤幸正・岡村 甫 : 異形鉄筋とコンクリート との付着に関する研究，コンクリート・ライブラリー第 2 号, 昭和 37 年 12 月

9）国分正胤・岡村 甫 : 鉄筋とコンクリートとの付着につい て, 第 2 回異形鉄筋シンポジウム, 昭和 40 年

10）国分正扸・多田美朝・立花一郎・松本嘉司 : 各種の高張 力異形鉄筋を用いた鉄筋コンクリート大型ばりの疲労に 関する研究, 土木学会論文集第 122 号, 昭和 40 年 10 月

11) W. Weibull : Fatigue Testing and Analysis of Results, Pergamon Press LTD., London, 1961

(1965.4.8 - 受付) 